This item was submitted to Loughborough's Research Repository by the author.

Items in Figshare are protected by copyright, with all rights reserved, unless otherwise indicated.

\title{
Validation of a numerical modelling technique for multilayered geosynthetic landfill lining systems
}

PLEASE CITE THE PUBLISHED VERSION

http://dx.doi.org/10.1016/j.geotexmem.2007.09.003

PUBLISHER

(C) Elsevier

VERSION

AM (Accepted Manuscript)

LICENCE

CC BY-NC-ND 4.0

\section{REPOSITORY RECORD}

Fowmes, Gary John, Neil Dixon, and D. Russell V. Jones. 2019. "Validation of a Numerical Modelling

Technique for Multilayered Geosynthetic Landfill Lining Systems". figshare. https://hdl.handle.net/2134/10296. 
This item was submitted to Loughborough's Institutional Repository (https://dspace.lboro.ac.uk/) by the author and is made available under the following Creative Commons Licence conditions.

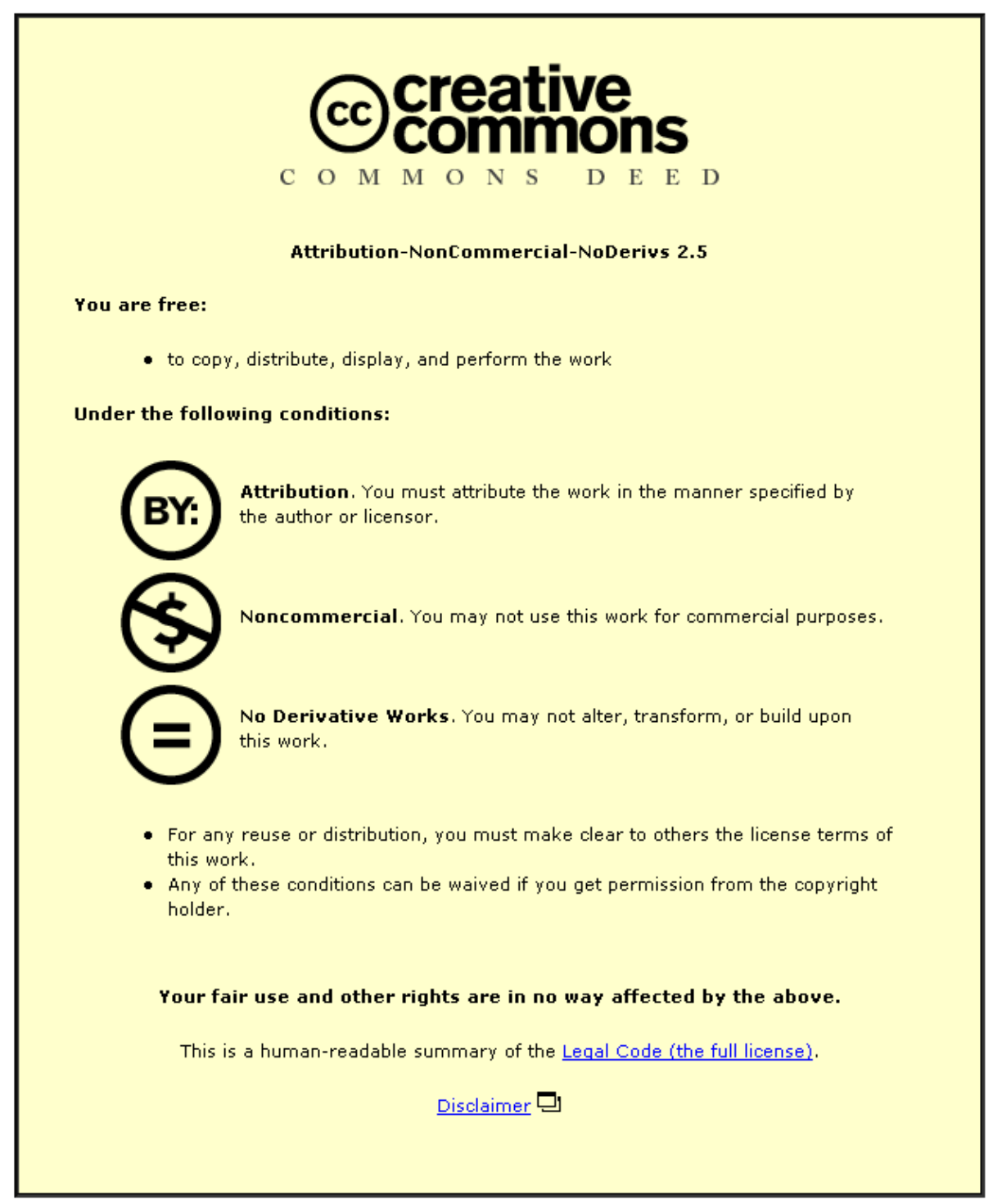

For the full text of this licence, please go to: http://creativecommons.org/licenses/by-nc-nd/2.5/ 


\section{Validation of a numerical modelling technique for multilayered geosynthetic landfill lining systems}

G.J. Fowmes ${ }^{1}$, N. Dixon ${ }^{2}$, and D.R.V. Jones ${ }^{3}$

${ }^{1}$ Geotechnical Research Engineer, Centre for Innovative and Collaborative Engineering, Department of Civil and Building Engineering, Loughborough University and Golder Associates (UK) Ltd. Tel: +44 (0) 115 9371111, Fax: +44 (0) 115 9371100, Email: gfowmes@golder.com

${ }^{2}$ Senior Lecturer in Geotechnical Engineering, Department of Civil and Building Engineering, Loughborough University, Leicestershire, LE11 3TU

Tel: +44 (0) 1509 228542, Fax: +44 (0) 1509 223945, Email: n.dixon@lboro.ac.uk

${ }^{3}$ Principal and Senior Geotechnical Engineer, Golder Associates (UK) Ltd, Attenborough House, Browns Lane Business Park, Stanton-on-the-Wolds, Nottinghamshire, NG12 5BL Tel: +44 (0) 115 9371111, Fax: +44 (0) 115 9371100, Email: rjones@ golder.com

5740 words; 2 tables; 14 figures

Version 2.01 4th September 2007 


\section{ABSTRACT}

It has become common practice to conduct numerical analyses to assess the stability and integrity of side slope landfill lining systems, however, information that can be used to validate such models is extremely limited. This paper contains data from a series of large scale laboratory tests containing geosynthetic elements of a multilayered lining system exposed to downdrag forces from a compressible synthetic waste material (rubber crumb). These data are compared to the results from numerical analysis of the same problem. The numerical results are from initial best estimate analyses, with interface and synthetic waste properties derived from a laboratory testing programme and geosynthetic material properties from manufacturers. The observed trends of tensile stresses in the geosynthetics and relative displacements at interfaces in the laboratory testing are reproduced by the numerical models to an acceptable degree of accuracy that would be appropriate, using site specific input data, for use in commercial design.

\section{Keywords}

Landfill design, numerical analysis, geomembrane tension, multiple layer lining systems, interface displacements. 


\subsection{INTRODUCTION}

Guidance on landfill stability assessment published by the UK Environment Agency (Dixon \& Jones, 2003) requires an assessment of both landfill stability and lining system integrity. Stability assessments of landfill lining systems are traditionally carried out by limit equilibrium techniques. However, such techniques cannot assess integrity (Long et al. 1994). The forces applied to the geosynthetic components, due to waste compression and degradation, are often overlooked in the design process. In order to represent compression and degradation controlled settlement induced downdrag, a model needs to represent the horizontal forces applied by the waste body and down drag on the lining system due to waste settlement. Previous studies by Fowmes et al. (2005 and 2006) have used the FLAC modelling code to assess the integrity of geosynthetics in multilayered lining systems. Whilst attention has been paid to accuracy of input parameters, it has been assumed that the model, including the implementation of multiple layered geosynthetic interface interaction, is correct.

Limited data is available for comparing measured behaviour of multiple layered geosynthetic lining systems to that predicted by numerical modelling techniques. Villard et al. (1999) present a model using Finite element modelling techniques, of a landfill lining system during construction and compare predicted behaviour to field measurements. This study showed a good correlation, however, the post waste placement data is not presented for either the field or numerical models due to a poor match between the data sets. The study reported in this paper aims to validate a numerical modelling technique by comparing interaction of geosynthetic landfill lining system components 
subjected to downdrag forces in a large scale laboratory model with the results of a numerical analysis of the same system.

\subsection{LABORATORY TESTING}

Large scale laboratory testing was carried out so that measured behaviour could be compared to a numerical model of the same system. It must be emphasised that the physical model is not intended to directly represent behaviour of a landfill lining system;

it was designed to represent the interaction of lining system components when exposed to downdrag forces and hence generate post-peak interface displacements experienced in side slope landfill lining systems. Thusyanthan et al., (2004) investigated tension in a scaled geomembrane on a shallow side slope in a centrifuge model, including dynamic loading, however, only a single geosynthetic was included in the lining system. A test without increased gravitational acceleration was adopted in this investigation as it allowed full scale geosynthetics to be used, and thus interface behaviour could be characterised using standard direct shear apparatus. A compacted clay barrier layer was not included in the laboratory model. Formation of a planar vertical face would have been problematic, as it would have introduced a number of additional variables (i.e. related to moisture content and density) and it is not routinely present directly beneath the geomembrane in steep slope lining systems in UK practice. A wood subgrade was employed, which could be readily characterised and used to represent geomembrane support systems on steep slopes. 


\subsection{Test chamber design}

The test chamber consisted of a $1 \mathrm{~m} \times 1 \mathrm{~m} \times 1 \mathrm{~m}$ void that was filled with compressible rubber crumb. One side of the test chamber was formed of a vertical wooden wall supported by a frame on which samples of geomembrane covered with a geotextile were placed (Figure 1). The front of the test chamber consisted of a $25 \mathrm{~mm}$ thick glass panel to allow movements in the system to be observed. The remaining two walls were sheet steel. The wooden subgrade was selected as it would provide a low friction interface beneath the geomembrane thus allowing measurable tensile strains in the geomembrane.

The sheet steel and glass walls of the test chamber were lined with a $0.1 \mathrm{~mm}$ thick sacrificial plastic sheet (shown in Figure 1) which reduced the friction between the box side and the compressible synthetic waste (rubber crumb) in order to lessen the edge effects imposed by the test chamber dimensions. The plastic sheet moved with the synthetic waste, allowing slip of the interface between the box side and sacrificial plastic layer. Direct shear testing showed that the interface friction angle between the rubber crumb and test chamber was $7^{\circ}$ when a sacrificial sheet was included. The low friction on the side wall, resulted in an observed compression in the lower $200 \mathrm{~mm}$ of the synthetic waste being equal to $91 \%$ of the settlement in the top $200 \mathrm{~mm}$ of the synthetic waste. Based on these measurements it was considered valid to model the experiment as a plane strain problem subjected to one dimensional compression.

A vertical slope was adopted to simplify load application, as a rigid plate of fixed dimensions was used for load application. This meant that the load application area could 
be kept constant, which reduced uncertainty in calculating the horizontal stress applied to the lining system.

\subsection{Synthetic waste}

Rubber crumb, with a grain size ranging from 2 to $8 \mathrm{~mm}$, was selected as a synthetic waste material as it has similar compression behaviour, shear strength and mobilised horizontal stresses to municipal solid waste. However, unlike waste it does not exhibit large heterogeneity which would be problematic in tests of this scale. As the rubber particles do not yield during compression (i.e. elastic particle compression and particle reorganisation occurs representing recoverable and non recoverable settlement respectively), the rubber can be reused.

The compressive behaviour of the rubber crumb was tested at different scales using a CBR mould, a $0.125 \mathrm{~m}^{3}$ test chamber and in the $1 \mathrm{~m}^{3}$ test chamber. The shear strength of the rubber crumb was measured using a 100 x $100 \mathrm{~mm}$ shear box. The material was sheared at $1 \mathrm{~mm} / \mathrm{min}$ in the first series of tests and $0.1 \mathrm{~mm} / \mathrm{min}$ in the second series of tests, with no perceptible difference in the behaviour under the more rapid shearing. The shear strength of the rubber crumb under direct shear can be defined by a friction angle of $29.3^{\circ}$ and an apparent cohesion of $3 \mathrm{kPa}$.

\subsection{Geosynthetic materials}

A non-woven geotextile was used with tensile strength (in the machine direction) of $20 \mathrm{kN} / \mathrm{m}$, a thickness (at $2 \mathrm{kPa}$ ) of $3.9 \mathrm{~mm}$, and tangential tensile modulus (at $50 \%$ strain) of $1.2 \times 10^{4} \mathrm{kPa}$. The geotextile was not anchored at the top and therefore did not develop tension at the top. 
Three geomembranes were used in the investigation; two textured linear low density polyethylene (LLDPE) (one blown film, one impinged) geomembranes and one mono textured (impinged texturing) high density polyethylene (HDPE) geomembrane (tested both textured and smooth side up). The geomembrane properties are summarised in Table 1. The geomembrane was anchored at the top and therefore tension was able to develop.

\subsection{Load application}

A total of $75 \mathrm{kN}(7 \times 10 \mathrm{kN}$ hydraulic loading increments, and $5 \mathrm{kN}$ kentledge $)$ of load was applied to the upper surface of the compressible synthetic waste. A hydraulic four point loading system was used to apply up to $70 \mathrm{kN}$ to a rigid steel load plate (Figure 2). Due to the presence of the glass front to the test chamber the pressure application was limited to the $80 \mathrm{kPa}$ exerted at the base of the chamber ( $75 \mathrm{kN}$ applied load and $5 \mathrm{kN}$ from the self weight of the material). Vertical strains of $28 \%$ were generated in the synthetic waste using this loading arrangement, which compare with total waste settlements in the range $20 \%$ to $30 \%$ (Jones and Dixon, 2003)

\subsection{Instrumentation}

\subsubsection{Geosynthetic displacement}

The relative displacement of five points on each of the geomembrane and geotextile were measured by attaching $1 \mathrm{~mm}$ diameter wires to the geosynthetics. The extensometer wires were attached at distances of $200 \mathrm{~mm}, 400 \mathrm{~mm}, 600 \mathrm{~mm}, 800 \mathrm{~mm}$ and $1000 \mathrm{~mm}$ from the base of each geosynthetic and were attached by passing them through a preformed hole in the geosynthetic and securing them with a brass swage to prevent deformation of the 
attachment and the geosynthetic. Although it is acknowledged that creating a hole in the geomembrane would not be acceptable on site, this technique was used in the laboratory experiment as it created a smaller inclusion on the interface than the alternative if using a welded lug attachment. To prevent additional interaction with the geosynthetics, the wires were contained within brass tubing, $3 \mathrm{~mm}$ internal and $4 \mathrm{~mm}$ external diameter. This isolated the wires from the interface (i.e. so they could move freely) while providing adequate crushing resistance to avoid "pinching" of the wires. The wires were run, via pulley wheels, over displacement measuring boards (Figure 3) with each tensioned using a $200 \mathrm{~g}$ static weight.

\subsubsection{Geomembrane tensile stress}

The geomembrane samples were restrained in the vertical direction using a clamp attached to a fixed steel frame using two, $12 \mathrm{kN}$ limit and $1 \mathrm{~N}$ resolution, tensile load cells (Figure 3). The cells were attached to the aluminium flat bar geomembrane clamp to through a two plane articulated joint to allow the cells to remain parallel to the load even if small movements in the clamp alignment occurred. No movement of the clamp arrangement was observed during the tests. A rigid frame, constructed from steel box section with welded joints, was assembled from which the tensile load cells were hung. Preliminary load tests were carried out with linear variable displacement transducer (LVDT) attached to ensure that deformations in the load cell support structure would not influence the readings. 


\subsubsection{Load plate displacement}

An MTS Temposonics position sensor was used to measure the vertical displacement of the rigid loading plate. Vertical displacement of the load plate was measured a distance of $50 \mathrm{~mm}$ from the lining system, and located centrally (Figure 2). A four point loading system was used to retain the horizontal orientation of the loading plate.

\subsubsection{Horizontal stress}

In a separate series of tests, the horizontal stresses at the synthetic waste - lining system interface were measured using vibrating wire pressure cells. Two $400 \mathrm{~mm}$ x $400 \mathrm{~mm}$ cells were placed in the test chamber, one placed horizontally at a depth of $650 \mathrm{~mm}$ from the rigid and uncompressed lining support surface (350 $\mathrm{mm}$ from the base) and the other placed vertically, mounted in the lining support system, located with its centre coinciding with the plane of the horizontal cell. The loading sequence, of $5 \mathrm{kPa}$ kentledge and $7 \mathrm{x}$ $10 \mathrm{kPa}$ hydraulic load increments, was applied, and readings taken from both pressure cells. To verify the readings taken from the cells, the test was then repeated with the two cells interchanged, and horizontal : vertical stress ratio calculated for each test and each cell. The results showed that the horizontal pressure at the interface increased linearly with increasing vertical pressure and the ratio of the horizontal to vertical pressure $\left(\mathrm{K}_{0}\right)$ was 0.55 (with a standard deviation of 0.013 for the 4 readings).

\subsection{INTERFACE SHEAR STRENGTH}

Interface shear strength involving geosynthetics can show considerable variability (Koerner \& Koerner 2001, Stoewahse et al. 2002), therefore, material specific interface shear tests were carried out on the materials used in the laboratory investigation. Three 
types of interface were tested in a direct shear apparatus with a shear area of $300 \times 300$ mm designed specifically for measuring geosynthetic interface behaviour:

- Wood subgrade - Geomembrane

The geomembrane was clamped to the lower (moving) box, whilst the load was applied to the wood placed in the (stationary) upper box.

- Geomembrane-Geotextile

The geomembrane was clamped to the lower box and the geotextile was attached to the upper box. Load was applied to the geotextile through a $50 \mathrm{~mm}$ layer of synthetic waste.

- Geotextile - Synthetic waste

The geotextile was clamped to the lower box. The upper box contained a $50 \mathrm{~mm}$ thick layer of synthetic waste through which the load was applied.

Normal stresses of 10, 30 and $50 \mathrm{kPa}$ were used to be representative of expected stresses acting normal to the lining system. Tests were carried out at a rate of $1 \mathrm{~mm} /$ minute to a displacement of $80 \mathrm{~mm}$. The shear stress displacement curves were then used to assess the interface stiffness and strain dependant interface shear strength properties for each combination of multilayered lining elements. It should be acknowledged that in some cases a true residual value of shear strength was not reached at the $80 \mathrm{~mm}$ displacement achieved in the shear box. 
Figures 4 and 5 show the direct shear results for lining systems involving LLDPE textured geomembranes Types $\mathrm{G}$ and $\mathrm{S}$ respectively. The synthetic waste-geotextile interface shear strength is the same in both cases, however, the interface shear strength of the Type G LLDPE geomembrane - geotextile interface is significantly higher than the Type S LLDPE geomembrane - geotextile interface. For lining systems involving mono textured HDPE geomembrane with the textured side up (Figure 6), the shear stress displacement curves are very similar to the Type G LLDPE geomembrane, as they both involve the same texturing type and are produced by the same manufacturer. For lining systems involving mono textured HDPE geomembrane with the smooth side up (Figure 7), the geotextile - geomembrane interface strength is clearly much lower than in the other cases. The presence of texturing has little effect on the smooth wood subgrade geomembrane interface as there are no appreciable asperities on the wood with which the texturing can interact. The peak and large displacement shear strengths are summarised in Table 2.

\subsection{NUMERICAL MODELLING}

The finite difference numerical explicit modelling code FLAC (version 4.00) has been selected to analyse side slope lining systems primarily due to its ability to model large strains and previous experience using it to assess multilayered geosynthetic interfaces (Fowmes et al. 2005, 2006).

\subsection{Modelling grid}

The finite difference modelling grid used in the analysis consists of 3 zones of elements, representing the wood subgrade, the compressible synthetic waste and the relatively 
incompressible steel test chamber side. In the modelling grid, before deformation, each zone represents a $20 \mathrm{~mm}$ x $20 \mathrm{~mm}$ cube of material under plane strain conditions (Figure 8).

\subsection{Constitutive model for synthetic waste}

The synthetic waste has been modelled using a linear elastic material model with a MohrCoulomb failure criterion, with shear strength parameters of $29.3^{\circ}$ friction angle and $3 \mathrm{kPa}$ apparent cohesion. By necessity the numerical modeller must simplify the real world problem and in commercial modelling applications, particularly for municipal solid waste, it is common practice to use a linear-elastic constitutive model with a MohrCoulomb failure criterion. Hence it is considered appropriate to assess the validity of the modelling process using this commonly applied constitutive material model. A limitation of using a linear elastic Mohr-Coulomb constitutive model is that the volumetric strain hardening of the synthetic waste is simplified to a linear modulus. A model with coupled volumetric and shear behaviour which are interdependent may be more appropriate in the case of synthetic waste. Although with two modes of internal deformation, particle deformation and particle rearrangement occurring, the synthetic waste has complex behaviour that cannot be currently modelled using commercially available material constitutive models. Using data from confined compression testing of the synthetic waste, as described in section 2.2, a secant constrained modulus (at $75 \mathrm{kPa}$ applied stress), was obtained and a Young's modulus of $189 \mathrm{kPa}$ was calculated. A Poisson's ratio of 0.25 was assumed to generate appropriate settlement and horizontal stress behaviour. 


\subsection{Modelling of geosynthetics}

The geosynthetic elements have been represented in the model using structural beam elements (following Itasca, 2002). Multiple beam elements can be placed in the nulled region between two grid elements, in this case one grid representing the synthetic waste and the other grid representing the wooden subgrade. The beams only interact, with each other and with the grid, through interfaces, which control the interface shear and normal displacement characteristics.

The beams were modelled using a linear elastic law, however, code was written to allow for the material to have a lower modulus in compression than in tension. An arbitrary value of $\mathrm{E}_{\mathrm{Tension}}=10\left(\mathrm{E}_{\text {Compression }}\right)$ was adopted from experience to ensure that in compression the interface properties control the compression behaviour rather than a rigid beam resisting compression. This is similar to the approach adopted by Villard et al. (1999), who used a compressive stiffness of 20 and 10 times lower than the tensile stiffness for the geotextile and geomembrane respectively. Each beam element, prior to deformation, measured $20 \mathrm{~mm}$ in length.

Tensile strength data for the geomembranes and geotextiles was acquired from the manufacturers. The data for the LLDPE geomembranes included a $2 \%$ strain secant modulus which was considered appropriate for use in the investigations as preliminary calculations predicted strains of this magnitude. Data supplied for the HDPE geomembrane gave yield stress and strain values allowing a secant modulus at yield, however, this greatly underestimates the small strain $(<2 \%)$ modulus. Giroud (1994) shows the $2 \%$ secant modulus of a HDPE to be over 3.5 times greater than a secant 
modulus at yield. It was thus decided to adopt a small strain tensile modulus (based on a $2 \%$ secant modulus), as this represented the appropriate magnitude of strain expected in the analysis. It is not recommended that $2 \%$ modulus values be adopted in design as this may result in overestimation of the material stiffness at strains in excess of $2 \%$. In such cases, a conservative secant modulus at yield, or, if sufficient data is available, a strain dependant modulus may be adopted.

\subsection{Interface modelling}

Each interface represents, prior to deformation, a contact length of $20 \mathrm{~mm}$. Interfaces are given normal and shear stiffness values, and interface shear strength. The normal stiffness is taken as an arbitrarily high value to maintain numerical stability and solution speed, whilst avoiding any appreciable interpenetration. Interpenetration of interfaces, where one side of the interface passes into the other and an overlap of grid zones occurs, can be a particular problem when modelling large strain problems across multilayer lining systems as the interpenetration is cumulative across all of the interfaces in the lining system.

The interface model uses initial stiffness values, measured from the direct interface shear tests, and displacement dependent limiting shear strength values (failure envelope). A user coded piecewise function is used to define the relationship between the failure envelope and the relative interface shear displacements. Input data for this function is derived from direct interface shear tests. Verification of this method is provided by comparing the relative shear displacements calculated by this code and the relative shear displacements (RSD) calculated manually from node and grid position data. The strength 
parameters were defined as a strain dependant law through piecewise friction angle against displacement and adhesion against displacement functions. The $80 \mathrm{~mm}$ shear strength values in the measured direct shear tests were taken as large displacement values which remained constant with further displacement. A simple Mohr-Coulomb linear elastic interface, with a friction angle of $7^{\circ}$, is included between the synthetic waste and test chamber side.

\subsection{Modelling of load application}

The load was applied using a vertical stress to the upper surface of the grid. It is acknowledged that this allows for some slight deformation in the upper surface of the synthetic waste, whereas in the laboratory experiment, the upper surface of the synthetic waste remains horizontal due to the rigid load plate. Attempts were made to model the rigid load plate; however, this resulted in numerical instability (calculation difficulties) induced by the large stiffness gradient between the load plate and the synthetic waste. It was thus decided to apply the load directly to the upper surface of the synthetic waste.

\subsection{RESULTS}

\subsection{Textured LLDPE geomembrane (Type G)}

Two tests were carried out, T2 and T5, using Type G textured LLDPE geomembrane. The interface shear stress displacement curves for these tests are shown in Figure 4, whilst the results from the numerical and laboratory modelling are shown in Figure 9 as relative shear displacements at the interfaces. The two laboratory tests show similar results, indicating that behaviour of the test is repeatable. As the peak strength is higher for the geomembrane - geotextile interface than the geotextile - synthetic waste interface 
(Table 2), the largest relative shear displacements occur between the synthetic waste and geotextile and the displacements measured between the geotextile and geomembrane do not reach post peak values. The FLAC model showed a similar trend, although the constitutive model used did underestimate the displacement, between the synthetic waste and geotextile at depth in the synthetic waste profile.

The FLAC model shows a similar trend to the laboratory model for the displacements between the geomembrane and the wood subgrade, however, the model underestimated the displacement (and hence extension of the geomembrane). Most of the discrepancy occurs at the upper sampling point, in the unconfined section of geomembrane above the level of the (undeformed) synthetic waste. It may be the case that the secant modulus used underestimates the tensile strength at the strains developed in this investigation. A comparison between the tensions developed at the geomembrane anchorage in all of the laboratory tests and in the numerical analysis is shown in Figure 10. The maximum values recorded in the laboratory tests are 3.49 and $3.47 \mathrm{kN} / \mathrm{m}$, whilst the FLAC analysis gives a maximum value of $3.93 \mathrm{kN} / \mathrm{m}$. This is considered to be an acceptable correlation.

\subsection{Textured LLDPE geomembrane (Type S)}

Unlike the Type G LLDPE geomembrane, which was delivered from the factory, the Type S LLDPE geomembrane was obtained from site and had some clay deposits on the surface. In the first test, T6, the clay was removed using a damp cloth, however, it was subsequently thought that this may have damaged the texturing on the surface of the material, and as such a second test, T9, was carried out where the geomembrane was cleaned using a water jet. 
The interface displacements show significantly greater displacements between the geomembrane and geotextile in T6 than in T9 (Figure 11) indicating that the cleaning process in T6 had damaged the texturing and lowering the interface shear strength. As a result the displacement between the geotextile and synthetic waste were lower in T6. The shear box tests used to derive the numerical input parameters were carried out on water cleaned geomembrane samples as in T9 and the results of the FLAC modelling shows good correlation to T9. The interim displacements between the geotextile and the synthetic waste are underestimated by the FLAC model and this is likely to be because the secant stiffness was chosen for the waste material rather than a volumetric strain hardening model.

The tension developed in the geomembrane during the test is shown in Figure 10. The tensile force at the geomembrane anchorage in $\mathrm{T} 9(2.36 \mathrm{kN} / \mathrm{m})$ shows a good correlation with the FLAC model $(2.57 \mathrm{kN} / \mathrm{m})$, while a lower value is recorded for T6 $(1.95 \mathrm{kN} / \mathrm{m})$ due to the lower transferred stress across the geotextile - geomembrane interface. Greater tension was developed when testing the Type G geomembrane compared to Type $S$ LLDPE due to the post peak strength reduction that occurred between the Type S LLDPE geomembrane and the geotextile which allowed increased displacement and lower shear stress transfer to the geomembrane.

\subsection{Mono-textured HDPE geomembrane (textured side up) (Type G)}

The displacements between the geomembrane - geotextile and the geotextile - synthetic waste interfaces (shown in Figure 12) are very similar to those shown in Figure 9 for Type G textured LLDPE geomembrane as they have the same texturing type and are from 
the same manufacturer, with the only difference being the polymer composition. The change in polymer type does reduce the displacement on the geomembrane - wood subgrade interface, due to the reduction in tensile strain in the geomembrane with the higher modulus HDPE geomembrane.

A comparison between the measured and modelled tension at the geomembrane anchorage is shown in Figure 10. A good correlation is observed between the measured and modelled value. The results show a small increase in measured tension compared to the Type G LLDPE geomembrane, possibly due to greater stress relaxation with increased strain in the LLDPE geomembrane. The behaviour of the FLAC model is very similar in both cases as the interface properties for the two analyses have very similar input parameters (see Table 2)

\subsection{Mono-textured HDPE geomembrane (smooth side up) (Type G)}

A second test was carried out on mono-textured HDPE geomembrane, in this case with the geomembrane placed smooth side up (i.e. against the geotextile). The effect on interface friction between the geomembrane and the wood was small $\left(<1^{\circ}\right.$ change in friction angle, see Table 2) However, there is a large reduction in interface shear strength between the geomembrane and the geotextile compared to the textured geomembrane geotextile interfaces and this resulted in large $(>200 \mathrm{~mm})$ displacements along this interface (Figure 13). As a result, the displacements on the geotextile - synthetic waste interface were reduced, and as less stress was transferred to the geomembrane, the geomembrane strains and geomembrane - wood subgrade displacements, were small. The FLAC analysis shows the same trends that were observed in the laboratory 
experiment. Although the FLAC analysis predicts more displacement between the geotextile and the synthetic waste and slightly less between the geomembrane and geotextile, the trend with depth of the displacements are well matched, as are the geomembrane - wood subgrade interface displacements.

The recorded maximum tensile force for T3 was $0.65 \mathrm{kN} / \mathrm{m}$ (Figure 10). This was much less than where a textured geomembrane - geotextile interface was present as the smooth geomembrane - geotextile interface results in lower stress transfer to the geomembrane. The FLAC model also shows the reduction in shear stress transferred into the geomembrane compared to textured membranes, although the shape of the curves with depth do not fit as well as for previous experiments. The constitutive model used for the synthetic waste may be responsible for this as a Mohr-Coulomb model generates sufficient horizontal stresses on the interfaces to transfer load into the lining system under self weight. However, at small loads the synthetic waste, which volumetrically hardens, does not generate sufficient shear stress in the lining system to cause tension in the geomembrane. Conversely, as the material stiffness increases with compression, there is increased stress transfer as shown at higher applied loads.

\subsection{DISCUSSION}

The FLAC numerical modelling using multiple strain softening interfaces has been shown to reproduce the behaviour of a two layered geosynthetic lining system subjected to downdrag forces from a compressible material (i.e. synthetic waste body). Some discrepancies between the measured and the modelled results have been observed, 
however the general trends of displacement and strain magnitudes are represented by the numerical modelling.

The constitutive model used for the synthetic waste in this investigation is not able to reproduce the full observed behaviour of the synthetic waste in compression as it does not account for the volumetric strain hardening, and this may account for some of the discrepancies between the FLAC and laboratory models. However, it was considered appropriate to use the linear elastic Mohr-Coulomb model as it is the most commonly applied in commercial design and reliable input parameters could be readily obtained.

For the Type G textured LLDPE geomembrane and the Type G HDPE geomembrane, textured side up, the FLAC model shows less displacement than the physical model at the synthetic waste geotextile interface. The laboratory results assume displacement of the rubber crumb is a simple function of compression at the upper surface, and measured values within the geosynthetics on the other side, however, the FLAC results show the relative positions of the grid and the beams (geosynthetics). The difference in these calculations is that the recorded values in the laboratory are omitting shearing of the synthetic waste, which accounts for the difference in the relative displacements compared to the FLAC predictions.

The representation of the geomembrane tensile load response is usually reported by manufacturers as stress and strain values at yield, and this may not be representative of stiffness behaviour at small strains, and can result in overestimation of predicted strain 
values. In this investigation $2 \%$ secant elastic moduli have been selected for the geomembranes and geotextile. This is still a simplification as stress strain response for geosynthetics is typically non linear and strain-rate dependent (Wesseloo et al., 2004) Ideally, a representative geomembrane model would include the full stress strain behaviour, obtained from wide width tensile tests, however, this data was not available for use in this study and is not commonly available for design.

In all of the analyses, but particularly when analysing the mono-textured HDPE geomembrane with the smooth side up, the model must account for compression of the geotextile, and compression of the lower portions of the geomembrane. Geotextile behaviour under compression is very difficult to model, firstly because the geomembrane compressive modulus under confined conditions is difficult to measure and secondly due to buckling failure modes occurring that result in formation of folds under high compressive strains (Villard el al., 1999). Geotextile folding is an extremely complex phenomenon to model numerically and although the modulus was reduced to account for reduced compressive stiffness when folds occur, modelling of actual folds is beyond the scope of continuum modelling techniques, particularly under commercially viable time scales. In the numerical modelling in this study, arbitrarily low compression stiffness was chosen so that compression behaviour was dependant on interface properties. However, at large compressions, where folding occurs this is still likely to underestimate the displacement of the geotextile. It is also observed in displaced samples that once folds form they tend to propagate at a point of focussed stress transfer into the geotextile. Figure 14 shows folding observed during the post test exhumation of Test T4, this 
resulted in greater geotextile compression in the lower $200 \mathrm{~mm}$ than the FLAC model predicted. The authors would suggest that designers consider the likely compressive strains in the system they are analysing, and if large scale compression of a geosynthetics is predicted they allow for inaccuracies of the modelling procedure when assessing numerical model outputs and deriving design factors of safety.

The FLAC model takes into account the complexities of synthetic waste behaviour, geosynthetic stiffness and interface shear strength mobilisation and post peak shear strength reduction, which is not possible in limit equilibrium analysis. The tension in the geomembrane was predicted by the FLAC model with a good degree of accuracy especially where a textured geomembrane - geotextile interface was present $(12 \%$ difference at $75 \mathrm{kN}$ applied load, for the Type G LLDPE geomembrane, and 8\% difference for the Type G HDPE geomembrane textured side up and for the Type $S$ LLDPE geomembrane). For the mono-texture HDPE geomembrane (smooth side up), the model prediction was less accurate (27\% difference at $75 \mathrm{kN}$ applied load) which is believed to be due in part to the simplified modelling of the compressive behaviour of the geomembrane.

The measured shear stress vs. shear displacement behaviour of geosynthetic interfaces is known to exhibit natural variability (Dixon. et al. 2006, Criley \& Saint John 1997). Between three and five direct shear tests were carried out in this study on each interface to determine the interface shear strength and stiffness characteristics. The interface shear strength values for the geomembrane - geotextile interface from the testing have been 
compared to those values published by Dixon et al. (2006) and to an internal database that includes tests at low normal stresses. The values show good correlation, although it is interesting to note the difference in interface shear strength between the Type S LLDPE geomembrane and the Type G LLDPE geomembrane, (Table 2) despite the fact that both are $1 \mathrm{~mm}$ textured LLDPE geomembranes.

The peak interface shear strength for the Type G geomembrane - geotextile interface is greater than that for the geotextile - synthetic waste, hence interface post peak strength reduction, and associated large displacements do not occur on this interface. Despite a lower post peak strength at the Type G LLDPE geomembrane - geotextile interface than at the geotextile - synthetic waste interface, as post peak shear strength reduction does not occur, slip occurs at the interface with the weaker peak strength; the geotextile synthetic waste interface. This agrees with Gilbert (2001) who states that the peak strengths are required to identify the location of slippage whilst the residual strengths are then needed to establish the residual strength of the system. The Type S geomembrane geotextile peak interface shear strength is lower than the peak strength for the geotextile synthetic waste interface, hence, post peak shear strength reduction occurs between the geotextile and geomembrane, with associated larger displacements. This highlights the importance of site specific interface shear strength testing. A designer selecting literature data for this scenario may greatly underestimate interface displacements, or geomembrane tension. It is acknowledged that even when the same tests are carried out by the same operator that interface shear strength variability occurs (Sia and Dixon, 2007) hence the measured strengths carried out in this investigation may have some 
variability from the actual interface strengths of the materials used in the model tests and this may account for some of the discrepancies between the measured and modelled test results.

The resolution of the displacement measuring equipment was limited to $\pm 0.5 \mathrm{~mm}$, allowing a strain resolution of $0.5 \%$ over a $200 \mathrm{~mm}$ gauge length. It is suggested that for further laboratory investigations that higher resolution displacement gauges would allow greater strain resolution and/or smaller gauge lengths. For field scale instrumentation it is suggested that the resolution used would be appropriate. The casing required to protect the wires would need to be revised for field scale experiments, as although the brass tubing was effective at laboratory scale, cost would likely inhibit its use at field scale. Under sloping lining systems, where a component of the self weight of the waste mass is also on the lining system, crushing resistance of the wire casing would become more important.

\subsection{FUTURE WORK}

The authors acknowledge that this investigation was to model the behaviour of a multilayered geosynthetic system subjected to downdrag forces and may not be representative of an actual landfill lining system. In particular, inclusion of a compacted clay liner underlying the lining system will make the model conditions representative of commonly used composite lining systems on shallow slopes but at the cost of significantly increased complexity. In order to further validate numerical models being used by designers and assess lining system behaviour, in addition to laboratory investigations on other material combinations, full scale field instrumentation of a landfill 
site should be carried out to assess model accuracy under real world conditions. The models reported here are focussed on waste like compression behaviour under self weight, and loading that would be applied by subsequent lifts of waste (i.e. only shortterm construction, filling, behaviour is considered). It would be beneficial to measure lining system behaviour in response to degradation induced settlement, and the stress and stiffness changes induced by this.

Stress transfer through overlying drainage (i.e. gravel) and protection layers plays an important role in waste barrier interaction. It is suggested that future work be carried out to assess the stability and integrity of drainage layers, to determine the stress transfer through such layers and the effect of draining layer instability on behaviour of underlying geosynthetic lining systems.

Development of new geomembrane instrumentation techniques such as fibre optics and thin film pressure gauges would allow less intrusive measurements and a potential higher degree of precision at both laboratory and field scale. Development of instrumentation under controlled laboratory conditions as described herein would allow calibration and assessment of instrument performance and durability under loading conditions prior to being used in field applications. Further work to estimate the effects of geosynthetic compression on numerical results should also be considered. 


\subsection{CONCLUSIONS}

The paper has shown that laboratory scale behaviour of multilayered geosynthetic lining system subject to downdrag forces can be represented, to a reasonable degree of accuracy using the large strain FLAC finite difference modelling techniques incorporating strain softening interfaces. There are some discrepancies between the modelled values and the measured behaviour, which the authors believe are due to simplifications in modelling geosynthetic axial stress response (both tension and compression) and in the constitutive model used to represent the synthetic waste (rubber crumb). However, it is concluded that the modelling code and application methodology are appropriate.

The numerical model represents geosynthetic materials in tension with far greater precision than in compression, as compressive moduli of geosynthetics in confined conditions are not available and are very difficult to measure. The complexity, from a numerical analysis perspective, is greatly increased by the presence of folding in the geotextile, which occurs at large compressive strains. It is beyond the scope of the FLAC numerical modelling code to analyse this process or to predict where it may occur.

The use of numerical modelling techniques allows prediction of displacements, stresses and strains in multilayer geosynthetic lining systems with non linear interface behaviour. However, the outputs are always limited by the accuracy of the input parameters, the constitutive equations and the application of the numerical calculation technique and this must be considered by the design engineer. The scope of this analysis was to assess the comparison between the laboratory model and the FLAC predictions and not to assess or 
predict the performance of a landfill lining system. Whilst it is believed that this project represents a significant step in the validation of the numerical model behaviour, full scale field instrumentation of a landfill site would allow for assessment of model accuracy under in service conditions.

\subsection{ACKNOWLEDGEMENTS}

Many thanks to GEOfabrics, Golder Associates and GSE Lining Technology Ltd. for supply of materials, and the EPSRC, CICE at Loughborough University, and Golder Associates for project funding.

\subsection{REFERENCES}

Criley, K.R. \& Saint John, D. (1997). Variability analysis of soil vs. geosynthetic interface friction characteristics by multiple direct shear testing. Proc. of Geosynthetics 1997, Long Beach, CA, 885-897.

Dixon, N. \& Jones, D.R.V. (2003). Stability of landfill lining systems: Guidance, Environment Agency Research and Development Project P1-385, Report 2.

Dixon, N., Jones, D.R.V. and Fowmes, G.J. 2006. Interface shear strength variability and its use in reliability-based landfill stability analysis. Geosynthetics International, 2006, (13) No1 p 1. 
Fowmes, G.J ., Jones, D.R.V. and Dixon, N. 2005. Analysis of a landfill directive compliant steepwall lining system. Proceedings 10th International Waste Management and Landfill Symposium, Sardinia.

Fowmes, G.J., Dixon, N., Jones, D.R.V. 2006 and Cowland, J. Modelling of Lining System Integrity. Proceedings 8th International Conference on Geosynthetics, Yokohama, Japan, pp207.

Gilbert, R.B. (2001) Peak versus residual strength for waste containment systems. Proc. GRI 15, Hot Topics in Geosynthetics II. pp29-39.

Giroud, J.P. (1994) Mathematical Model of Geomembrane Stress-Strain Curves with a Yield Peak. Geotextiles and Geomembranes. 13 (1994), 1- 22.

Itasca Consulting Group Inc. 2002, FLAC version 4.00 user's guide, Second revision, April 2002.

Jones, D.R.V. \& Dixon, N. (2003). Stability of landfill lining systems: Literature review, Environment Agency Research and Development Project P1-385, Report 1, pp 219.

Koerner, R.M. \& Koerner, G.R. (2001). Geosynthetics design beyond factor of safety; risk assessment using probability of failure analysis. Proc. GRI-15, Hot Topics in Geosynthetics-II, December 2001, Houston, 235-253. 
Long, J.H., Gilbert, R.B. and Daly, J.J. (1994) Geosynthetic Loads in Landfill Slopes: Displacement Compatibility. Journal of Geotechnical Engineering, Vol 120 No. 11 pp 2009. ASCE press.

Sia, A. H. I. and Dixon, N. (2007) Distribution and variability of interface shear strength and derived parameters. Geotextiles and Geomembranes 25 (2007) 139-154.

Stoewahse, C., Dixon, N., Jones, D.R.V., Blümel, W. \& Kamugisha, P. (2002).

Geosynthetic interface shear behaviour: Part 1 test methods, Ground Engineering, 35, 2 , $35-41$.

Thusyanthan, N.I., Madabhushi, S.P.G. and Singh, S. (2005) Tension in geomembranes on landfill slopes under static and earthquake loading - Centrifuge study. Geotextiles and Geomembranes 25 (2007) 78-95.

Villard, P., Gourc, J.P. and Feki, N. (1999) Analysis of geosynthetic lining systems (GLS) undergoing large deformations. Geotextiles and Geomembranes, 17 (1999) 17 - 32

Wesseloo, J., Visser, A.T. and Rust, E. (2004) A mathematical model for the strain-rate dependent stress-strain response of HDPE geomembranes. Geotextiles and Geomembranes 22 (2004) $273-295$. 
Table 1 Geomembrane properties

\begin{tabular}{|l|c|c|c|}
\hline & Type G LLDPE & Type S LLDPE & Type G HDPE \\
\hline Polymer Type & LLDPE & LLDPE & HDPE \\
\hline Manufacturer & Manufacturer G & Manufacturer S & Manufacturer G \\
\hline Texturing & Double & Double & Mono \\
\hline Texturing Type & Impinged & Blown film & Impinged \\
\hline $2 \%$ modulus & $4.2 \times 10^{5} \mathrm{kPa}$ & $4 \times 10^{5} \mathrm{kPa}$ & $7 \times 10^{5} \mathrm{kPa}$ \\
\hline Compressive modulus (assumed) & $4.2 \times 10^{4} \mathrm{kPa}$ & $4 \times 10^{4} \mathrm{kPa}$ & $7 \times 10^{4} \mathrm{kPa}$ \\
\hline Thickness & $1 \mathrm{~mm}$ & $1 \mathrm{~mm}$ & $1 \mathrm{~mm}$ \\
\hline Yield strength & & & $16 \mathrm{kN} / \mathrm{m}$ \\
\hline Yield Elongation & & & $9 \%$ \\
\hline Break Strength & $12 \mathrm{kN} / \mathrm{m}$ & $17.5 \mathrm{kN} / \mathrm{m}$ & $10 \mathrm{kN} / \mathrm{m}$ \\
\hline Break Elongation & $250 \%$ & $400 \%$ & $100 \%$ \\
\hline
\end{tabular}

Table 2 Summary of peak interface shear strengths

\begin{tabular}{|lccccc}
\hline Interface & $\alpha_{\text {peak }}(\mathrm{kPa})$ & $\delta_{\text {peak }}\left({ }^{\circ}\right)$ & $\alpha_{\text {LD }}(\mathrm{kPa})$ & $\delta_{\text {LD }}\left({ }^{\circ}\right)$ & Test \\
\hline Synthetic Waste vs. Geotextile & 4.4 & 29.9 & 3.3 & 29.8 & All \\
\hline Type G LLDPE GM vs. Geotextile & 8.2 & 27.5 & 5.6 & 16.5 & \multirow{2}{*}{ T2 \& T5 } \\
Type G LLDPE GM vs. Wood & 1.0 & 8.9 & 0.5 & 8.1 & \\
\hline Type S LLDPE GM vs. Geotextile & 1.0 & 29.0 & 2.0 & 18.8 & \multirow{2}{*}{ T6 \& T9 } \\
Type S LLDPE GM vs. Wood & 0.7 & 9.8 & 0.8 & 7.7 & \multirow{2}{*}{ T3 } \\
\hline Type G HDPE (tex) GM vs Geotextile & 8.0 & 29.4 & 5.4 & 18.7 & \multirow{2}{*}{ T4 } \\
Type G HDPE (smooth) GM vs Wood & 0.8 & 10.1 & 0.5 & 10.2 & \\
\hline Type G HDPE (smooth) GM vs Geotextile & 0.4 & 11.7 & 0.4 & 9.0 & \multirow{2}{*}{ Type G HDPE (tex) GM vs Wood } \\
Tyd & 0.8 & 9.2 & 0.4 & 8.0 & \\
\hline
\end{tabular}




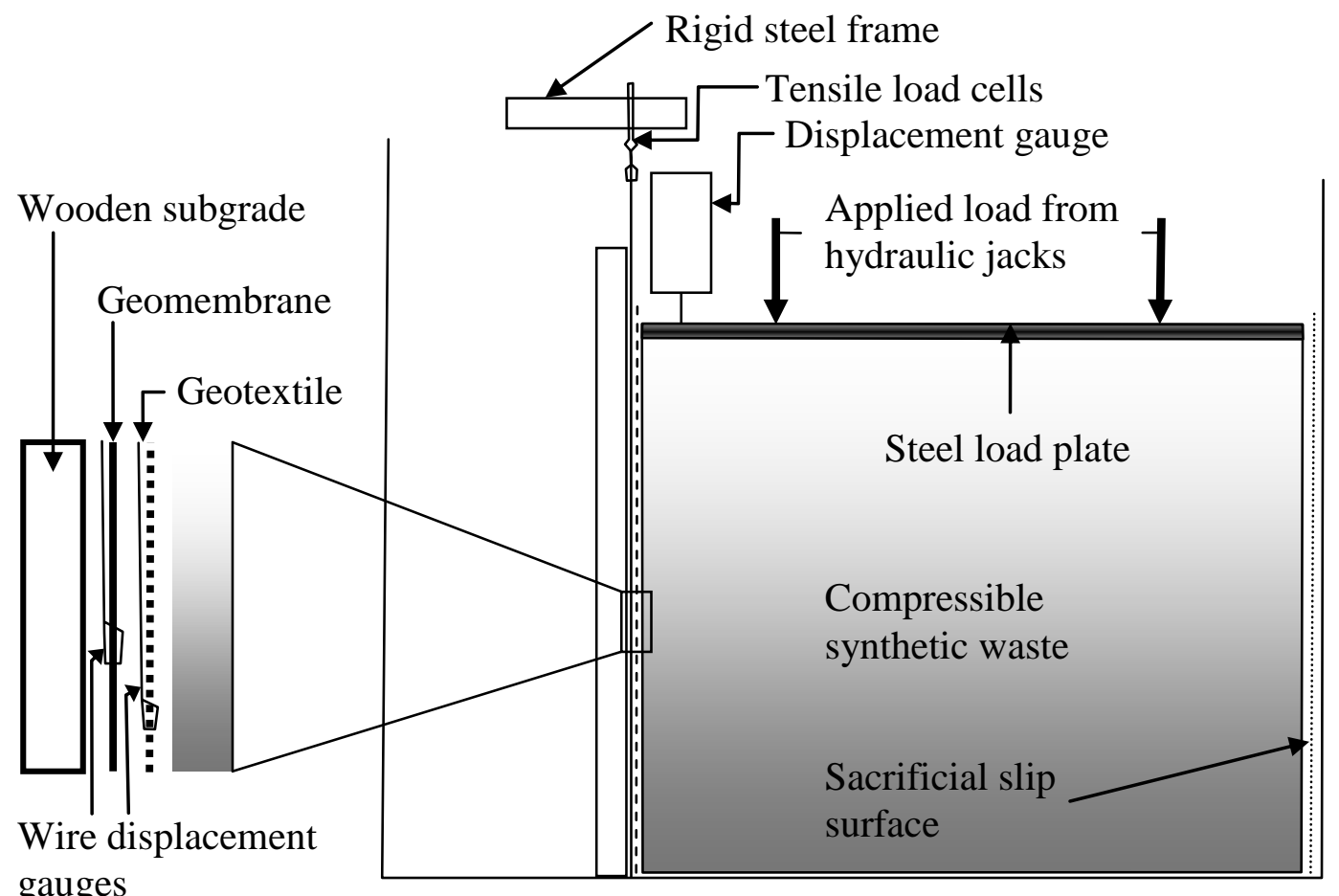

Figure 1 Schematic of measuring box

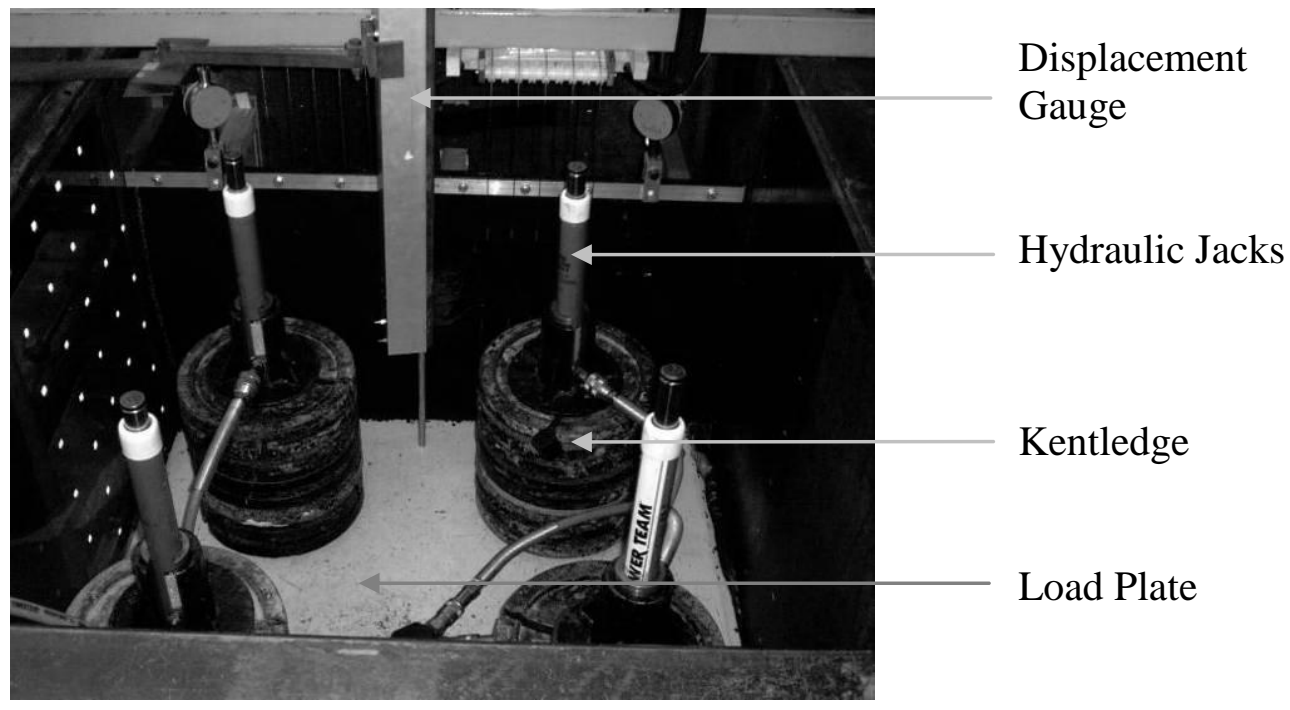

Figure 2 Photograph showing loading equipment 


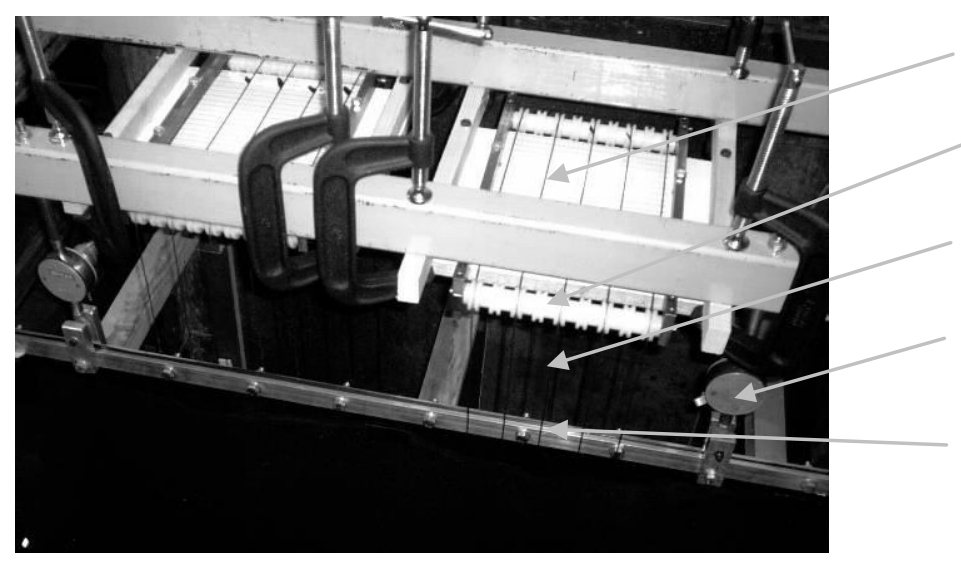

Measuring Board

Pulley wheels

Wires

Tensile load cell

Aluminium

geomembrane

clamp

Figure 3 Geosynthetic instrumentation

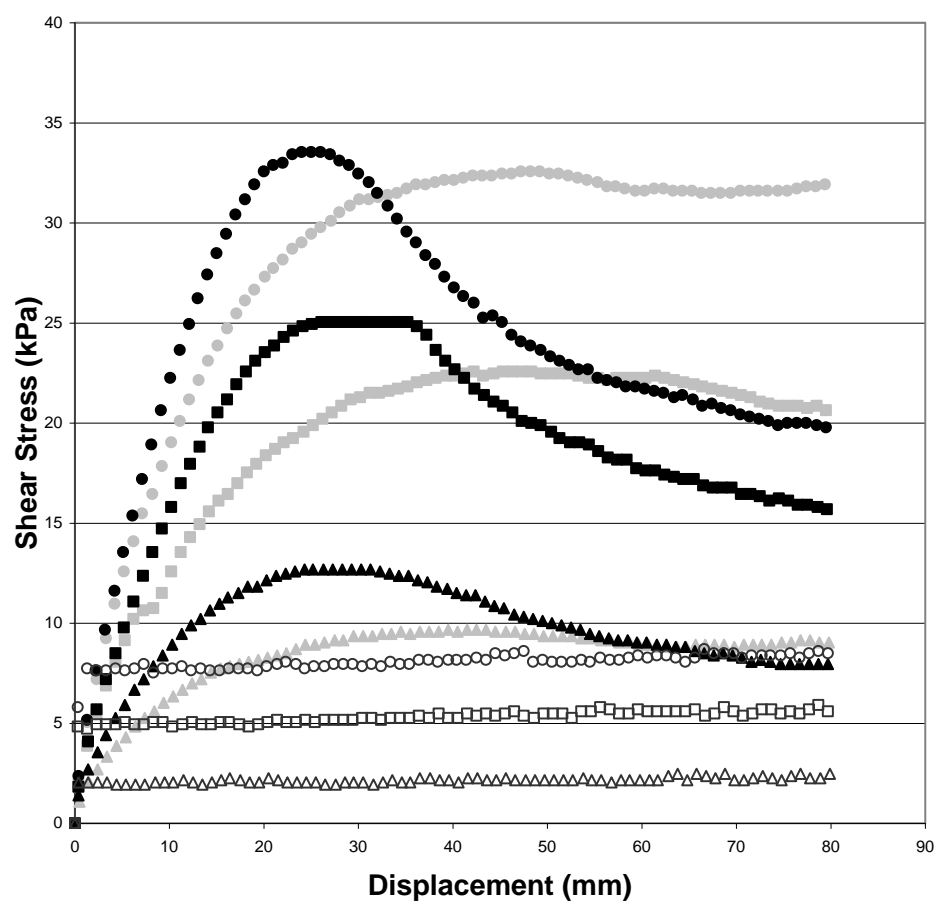

$\triangle$ Synthetic Waste v NWGT $10 \mathrm{kPa}$

- Synthetic Waste v NWGT $30 \mathrm{kPa}$

- Synthetic Waste v NWGT $50 \mathrm{kPa}$

\Type G Tex LLDPE GM vs NWGT $10 \mathrm{kPa}$

- Type G Tex LLDPE GM vs NWGT $30 \mathrm{kPa}$

- Type G Tex LLDPE GM vs NWGT 50 kPa

$\triangle$ Type G Tex LLDPE GM vs Wood $10 \mathrm{kPa}$

口 Type G Tex LLDPE GM vs Wood $30 \mathrm{kPa}$

- Type G Tex LLDPE GM vs Wood $50 \mathrm{kPa}$

Figure 4 Shear stress displacement curves measured from direct shear tests (Type G textured LLDPE Geomembrane). 


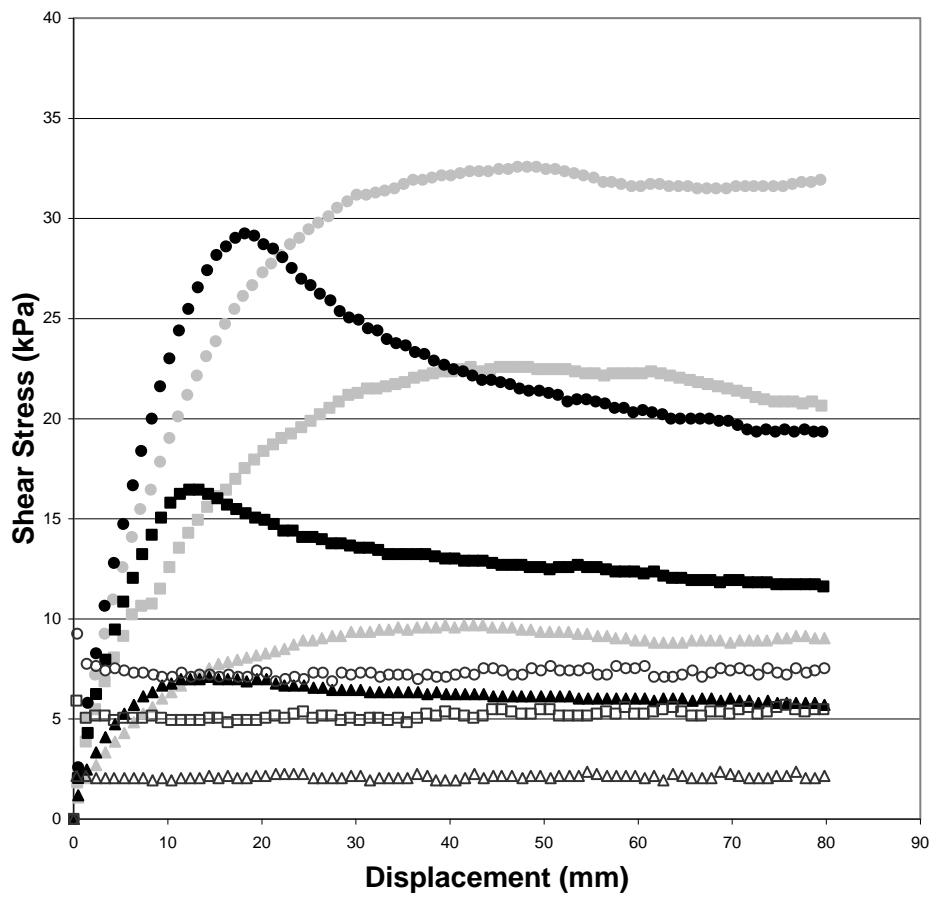

$\triangle$ Synthetic Waste v NWGT $10 \mathrm{kPa}$

- Synthetic Waste v NWGT $30 \mathrm{kPa}$

- Synthetic Waste v NWGT $50 \mathrm{kPa}$

$\triangle$ Type S Tex LLDPE GM vs NWGT $10 \mathrm{kPa}$

- Type S Tex LLDPE GM vs NWGT $30 \mathrm{kPa}$

- Type S Tex LLDPE GM vs NWGT $50 \mathrm{kPa}$

$\triangle$ Type S Tx LLDPE GM vs Wood $10 \mathrm{kPa}$

口 Type S Tex LLDPE GM vs Wood $30 \mathrm{kPa}$

- Type S Tex LLDPE GM vs Wood $50 \mathrm{kPa}$

Figure 5 Shear stress displacement curves measured from direct shear tests (Type $S$ textured LLDPE geomembrane).

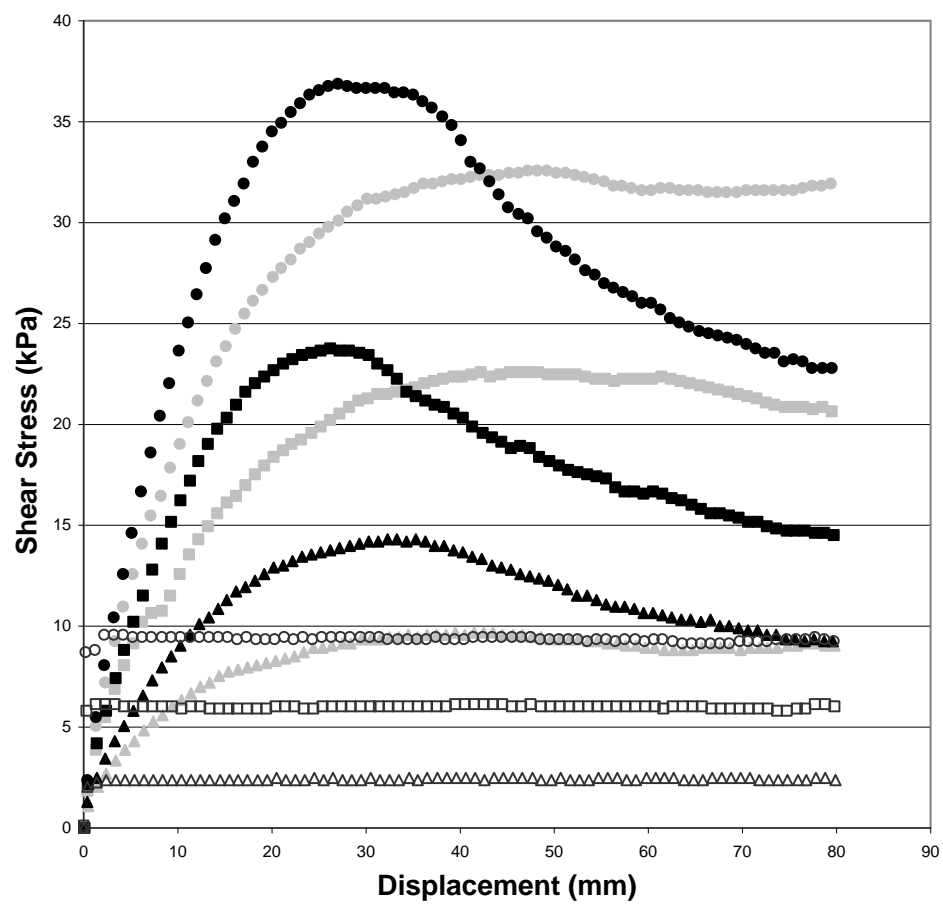

$\triangle$ Synthetic Waste v NWGT $10 \mathrm{kPa}$

- Synthetic Waste $v$ NWGT $30 \mathrm{kPa}$

- Synthetic Wastev NWGT $50 \mathrm{kPa}$

\Tex HDPE GM vs NWGT $10 \mathrm{kPa}$

- Tex HDPE GM vs NWGT 30 kPa

- Tex HDPE GM vs NWGT $50 \mathrm{kPa}$

$\triangle \mathrm{Sm}$ HDPE GM vs Wood $10 \mathrm{kPa}$

口 Sm HDPE GM vs Wood $30 \mathrm{kPa}$

- Sm HDPE GM vs Wood $50 \mathrm{kPa}$

Figure 6 Shear stress displacement curves measured from direct shear tests (Mono textured HDPE geomembrane, textured side up). 


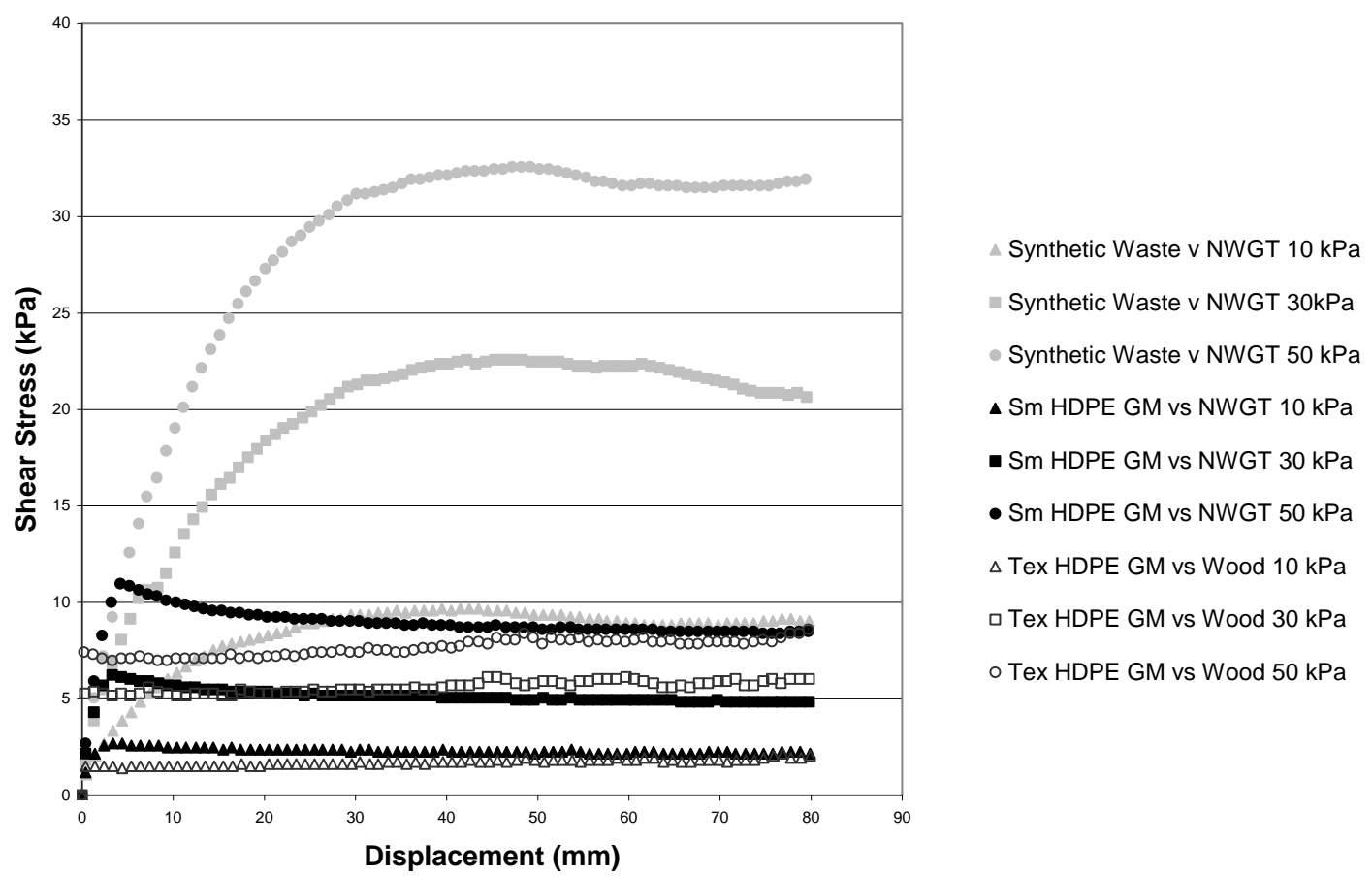

Figure 7 Shear stress displacement curves measured from direct shear tests (Mono textured HDPE geomembrane, smooth side up).

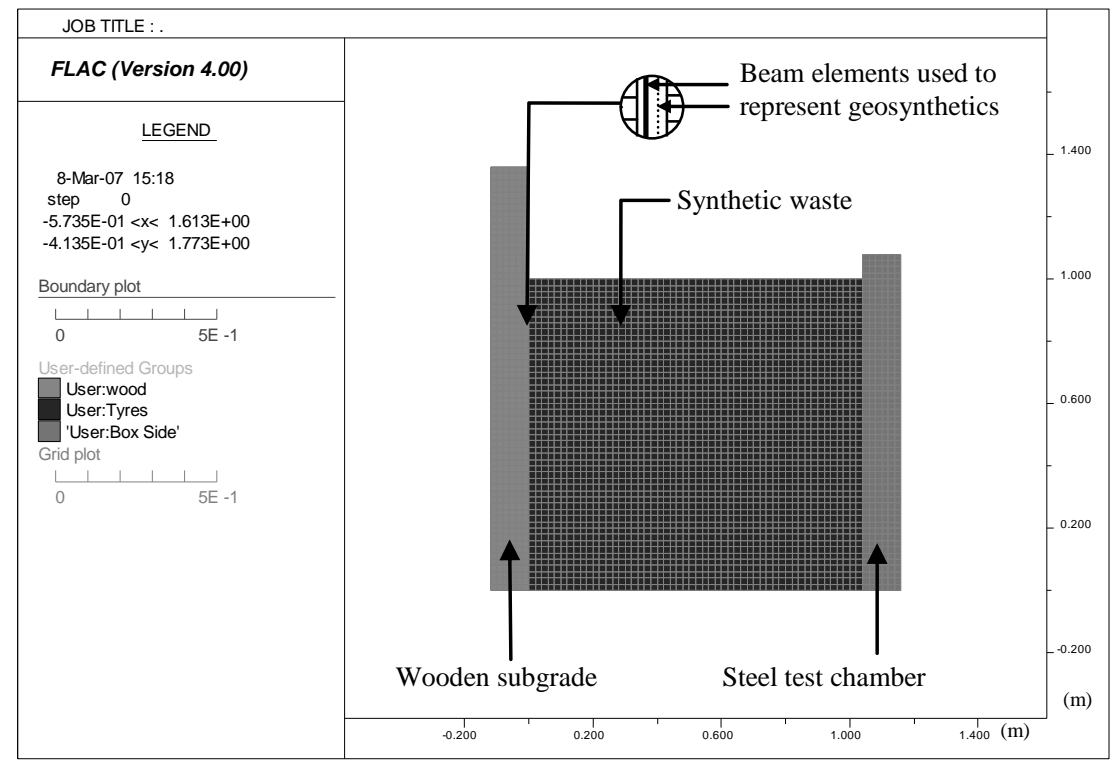

Figure 8 FLAC modelling grid used to assess model with $20 \mathrm{~mm}$ grid zones (prior to deformation). 
a)

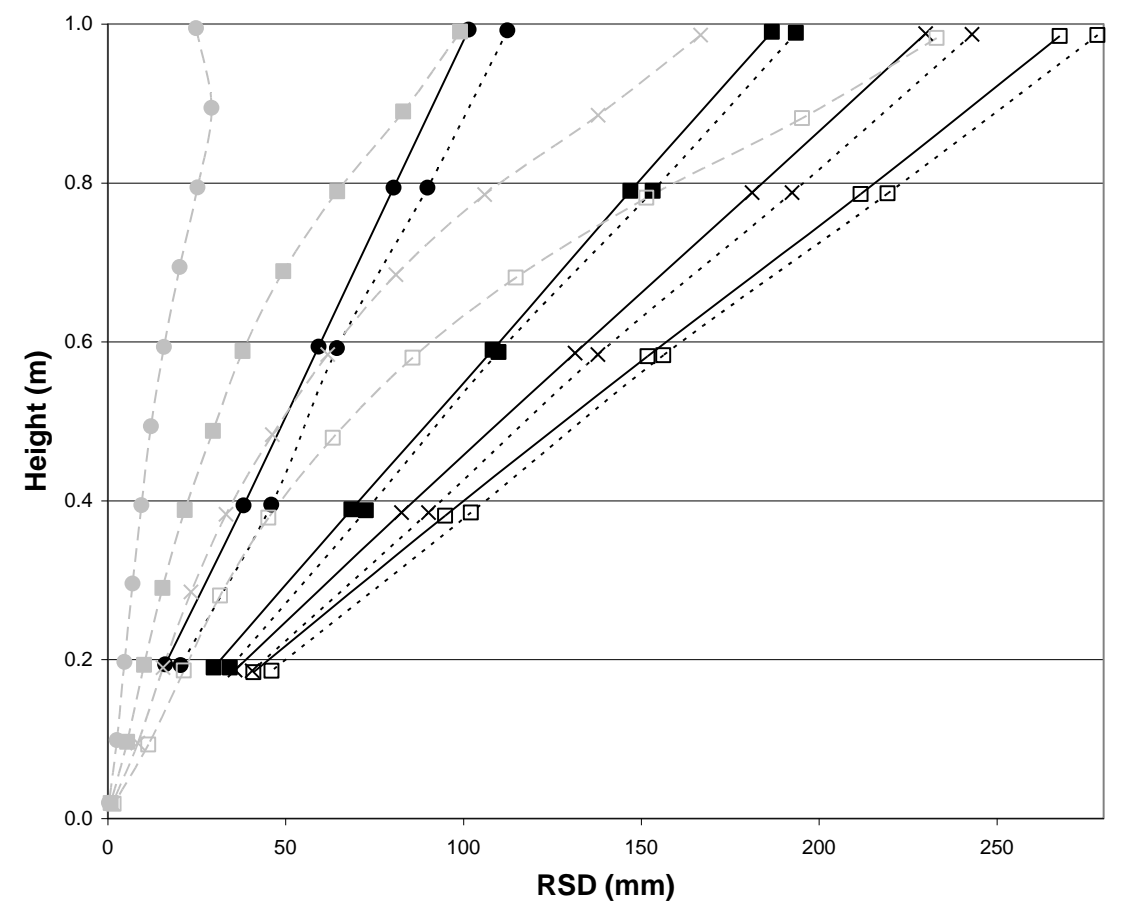

$\longrightarrow$ T2 $13.5 \mathrm{kPa}$

$\rightarrow-\mathrm{T} 235 \mathrm{kPa}$

$\longrightarrow \mathrm{T} 255 \mathrm{kPa}$

$\longrightarrow$ T2 $75 \mathrm{kPa}$

-. - T5 $13.5 \mathrm{kPa}$

-. $\mathrm{T} 535 \mathrm{kPa}$

-*. T5 $55 \mathrm{kPa}$

․

- - FLAC $13.5 \mathrm{kPa}$

- FLAC $35 \mathrm{kPa}$

$-x-$ FLAC $55 \mathrm{kPa}$

- $-\mathrm{FLAC} 75 \mathrm{kPa}$

b)

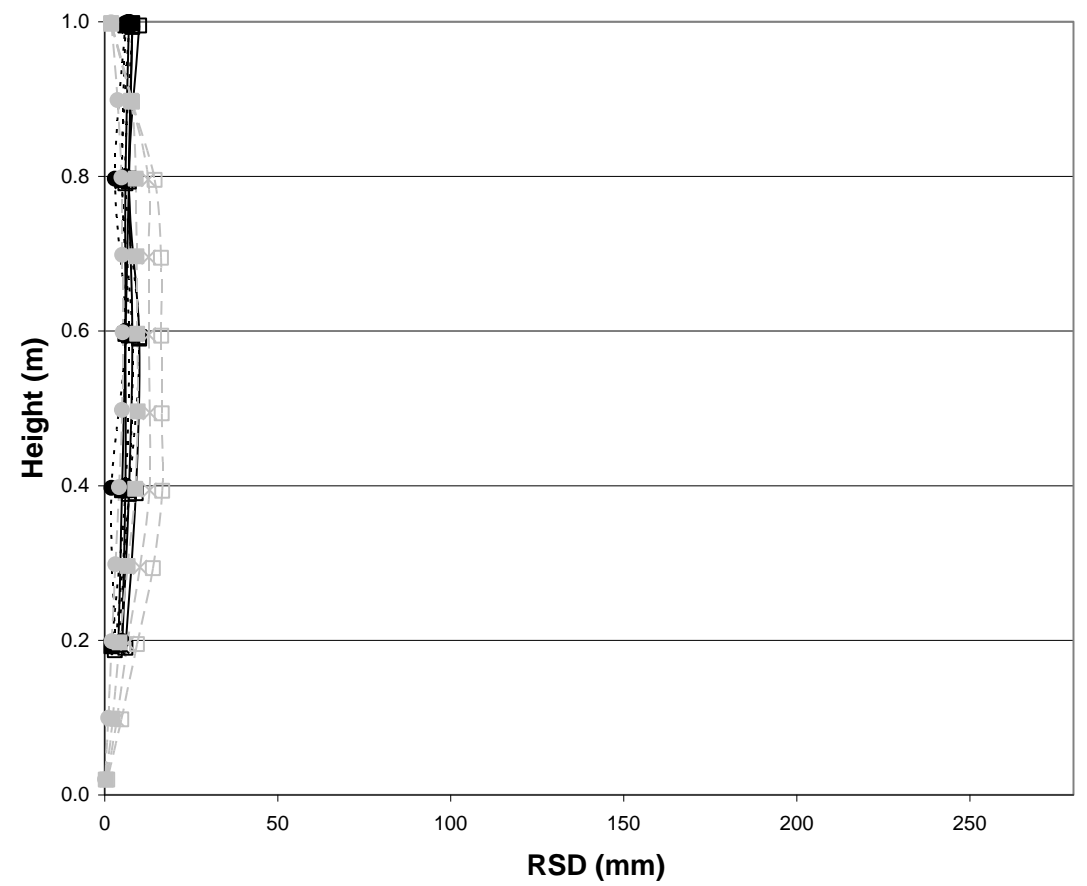

$\longrightarrow \mathrm{T} 213.5 \mathrm{kPa}$

$\rightarrow \mathrm{T} 235 \mathrm{kPa}$

$\leftarrow$ T2 $55 \mathrm{kPa}$

—-T2 $75 \mathrm{kPa}$

.•- T5 $13.5 \mathrm{kPa}$

-. - T5 $35 \mathrm{kPa}$

-.*. T5 $55 \mathrm{kPa}$

.• $\square$. T5 $75 \mathrm{kPa}$

FLAC $13.5 \mathrm{kPa}$

- FLAC $35 \mathrm{kPa}$

$-x-$ FLAC $55 \mathrm{kPa}$

- घ- FLAC $75 \mathrm{kPa}$

c) 


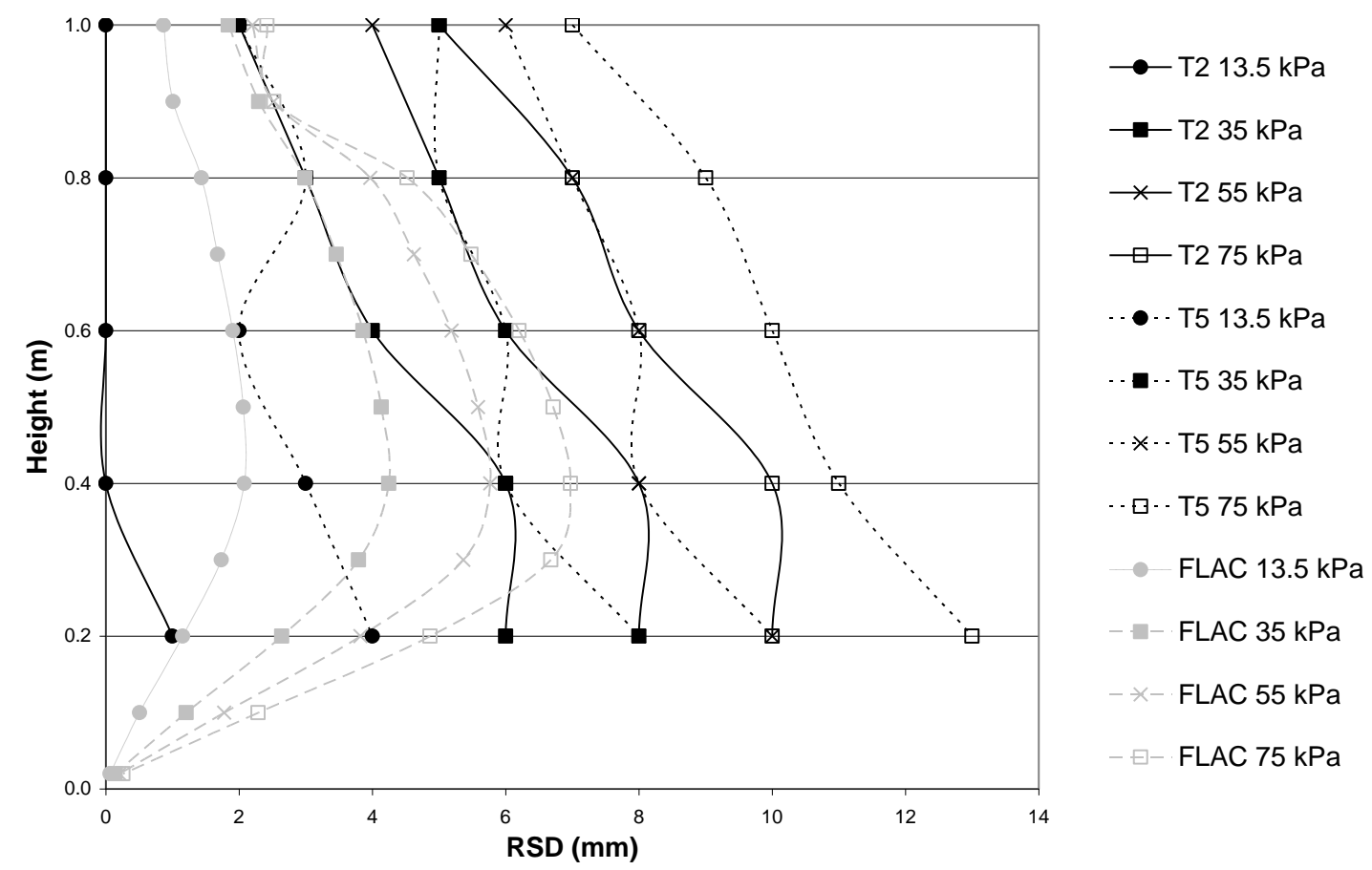

Figure 9 Relative interface shear displacements between a) synthetic waste vs. geotextile b) Type G textured LLDPE geomembrane vs. geotextile and c) Type G textured LLDPE geomembrane vs. wooden subgrade.

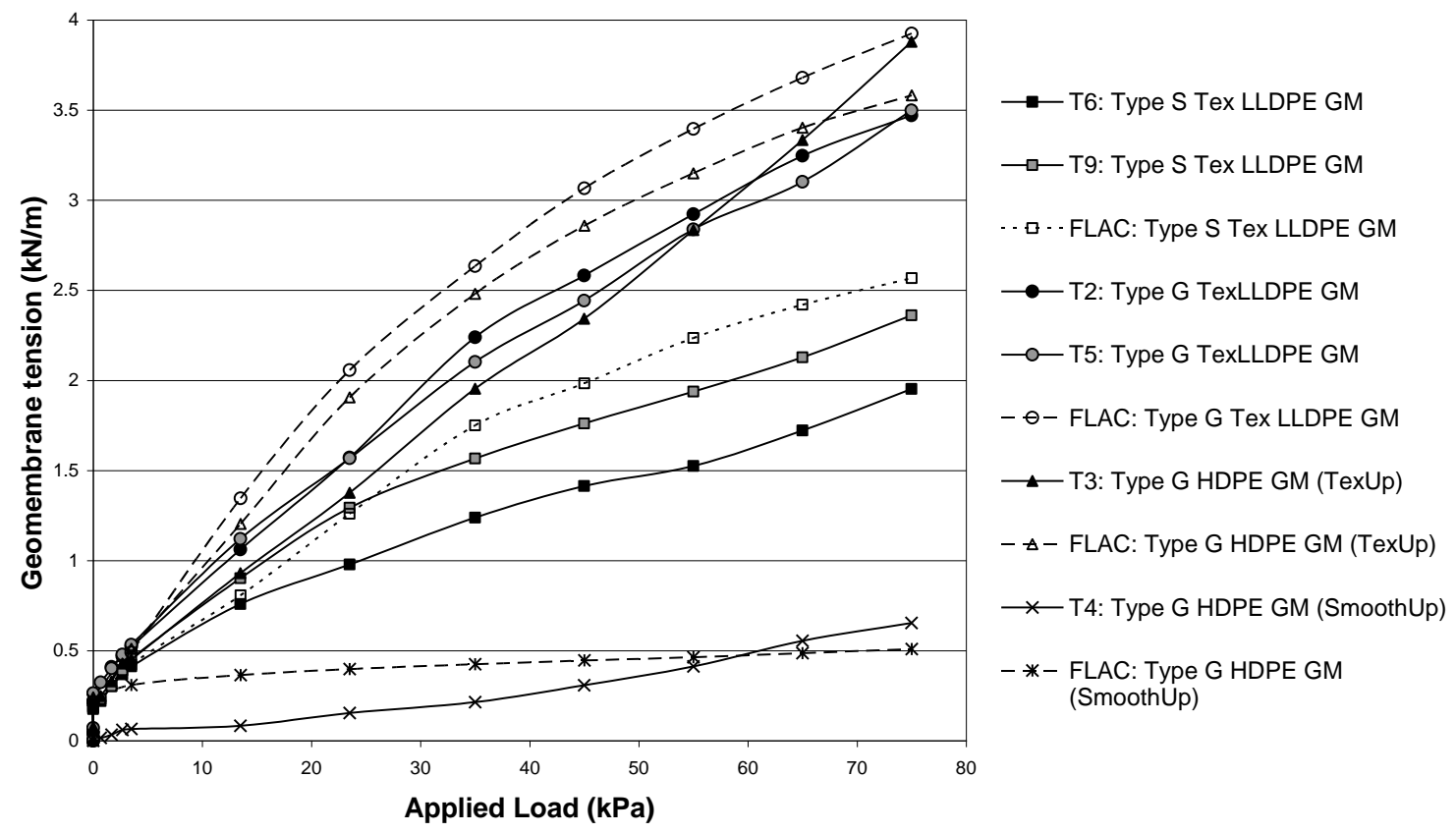

Figure 10 Tension in the geomembrane, at anchorage, from laboratory tests and FLAC models 
a)
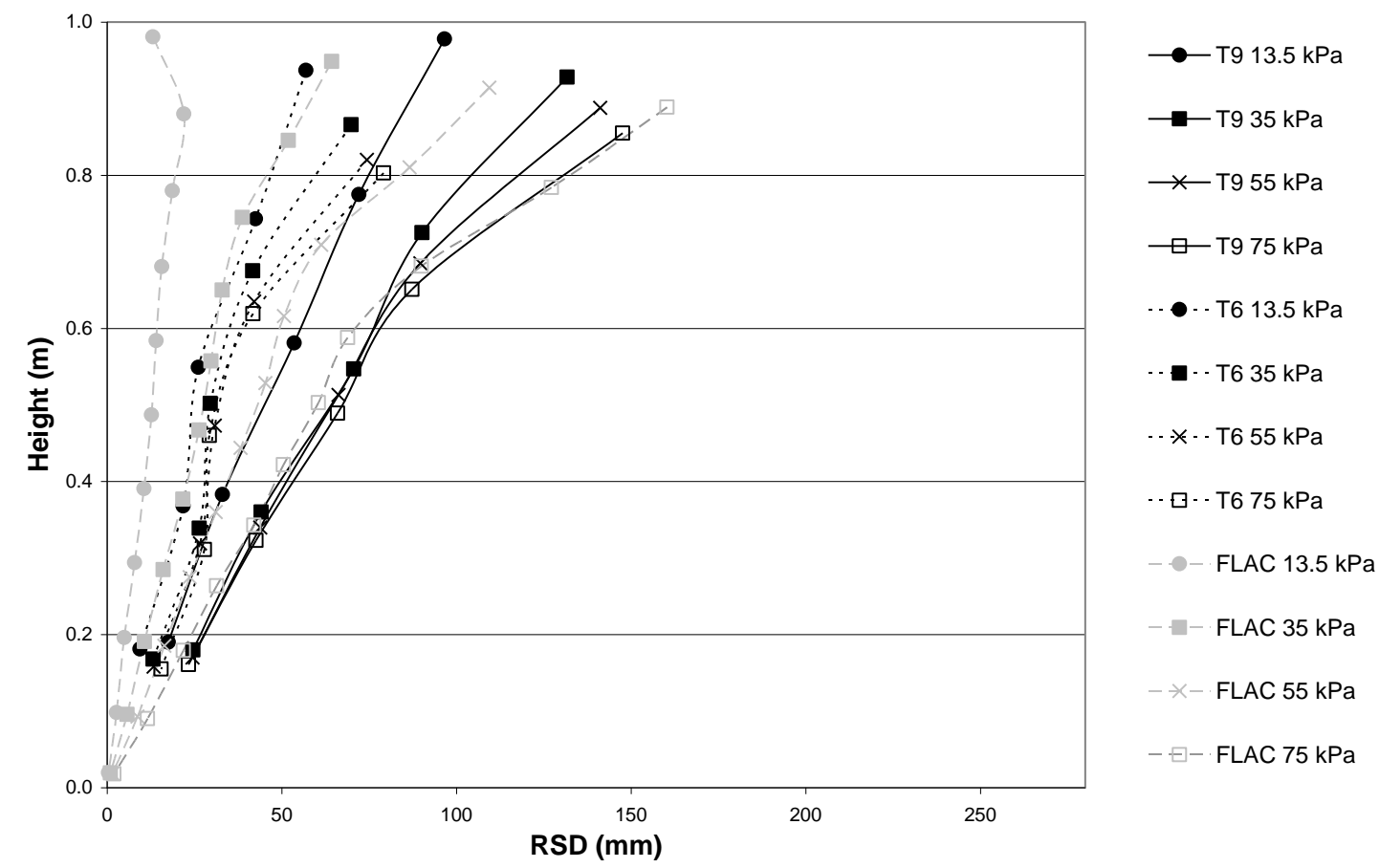

b)

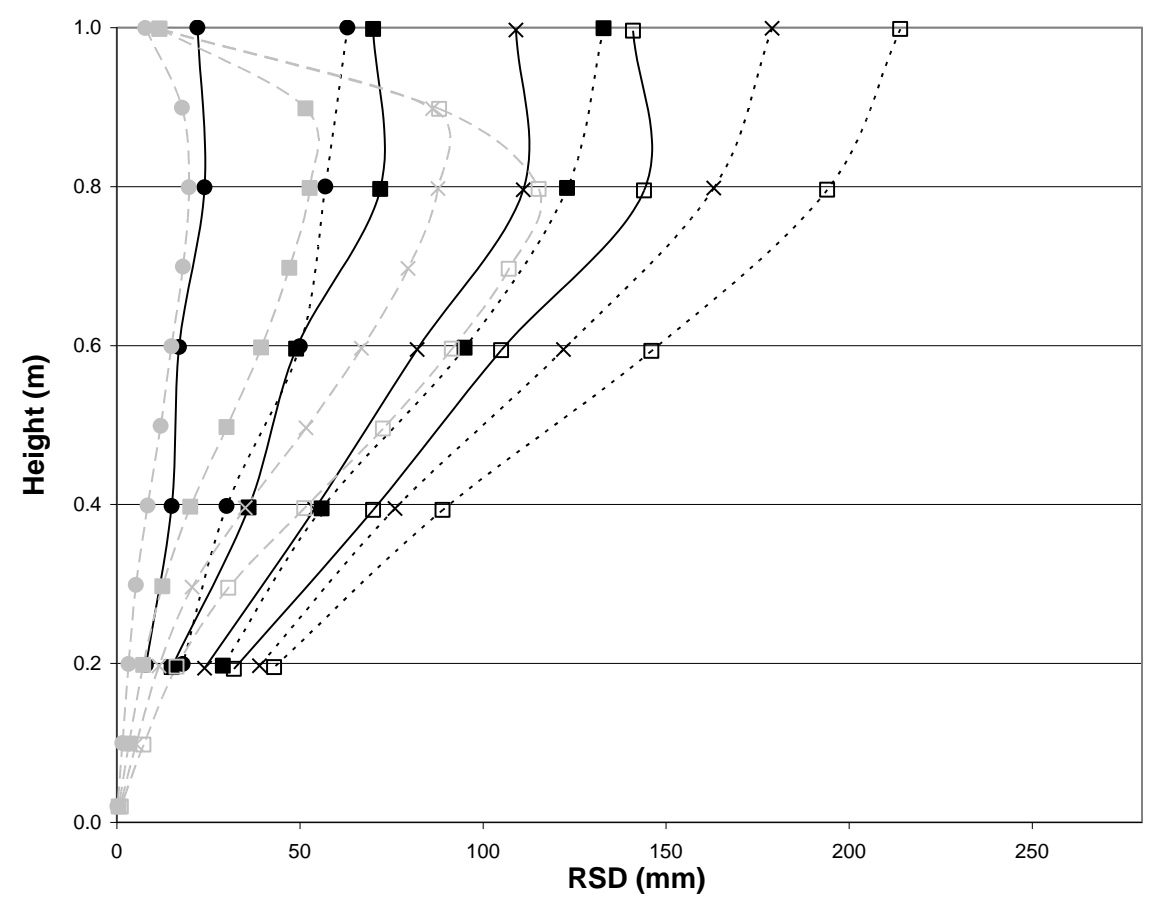

$$
\begin{aligned}
& \longrightarrow \text { T9 } 13.5 \mathrm{kPa} \\
& \text { - T9 } 35 \mathrm{kPa} \\
& \leftarrow \text { T9 } 55 \mathrm{kPa} \\
& \text { —-T9 } 75 \mathrm{kPa} \\
& \text {..- T6 } 13.5 \mathrm{kPa} \\
& \text {..- T6 } 35 \mathrm{kPa} \\
& \text {-.*- T6 } 55 \mathrm{kPa} \\
& \text {. घ. . T6 } 75 \mathrm{kPa} \\
& \text { - FLAC } 13.5 \mathrm{kPa} \\
& \text { - FLAC } 35 \mathrm{kPa} \\
& \text { x- FLAC } 55 \mathrm{kPa} \\
& \text { 曰- FLAC } 75 \mathrm{kPa}
\end{aligned}
$$

c) 


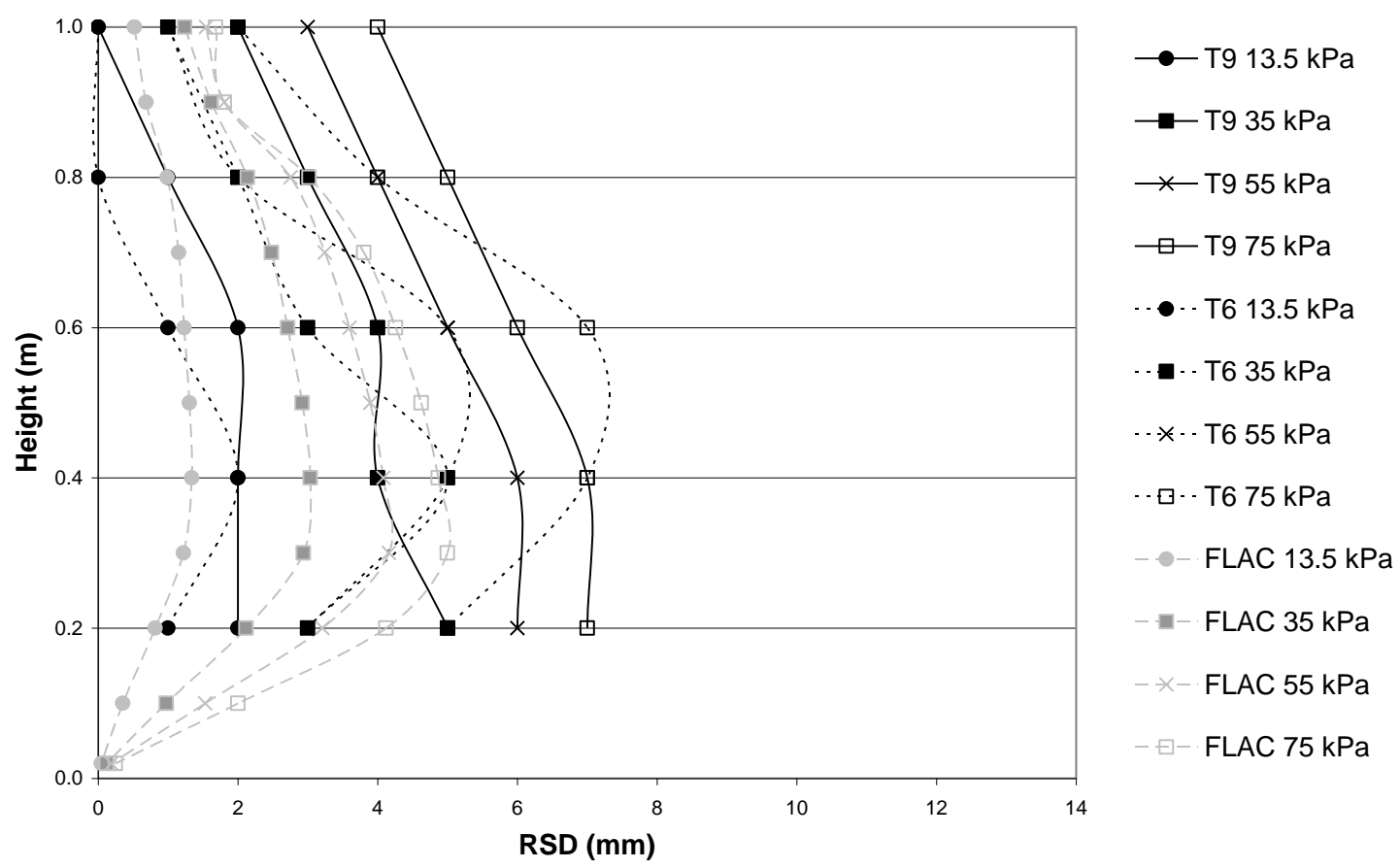

Figure 11 Relative interface shear displacements between a) synthetic waste vs. geotextile b) Type $S$ textured LLDPE geomembrane vs. geotextile and c) Type $S$ textured LLDPE geomembrane vs. wooden subgrade. 
a)

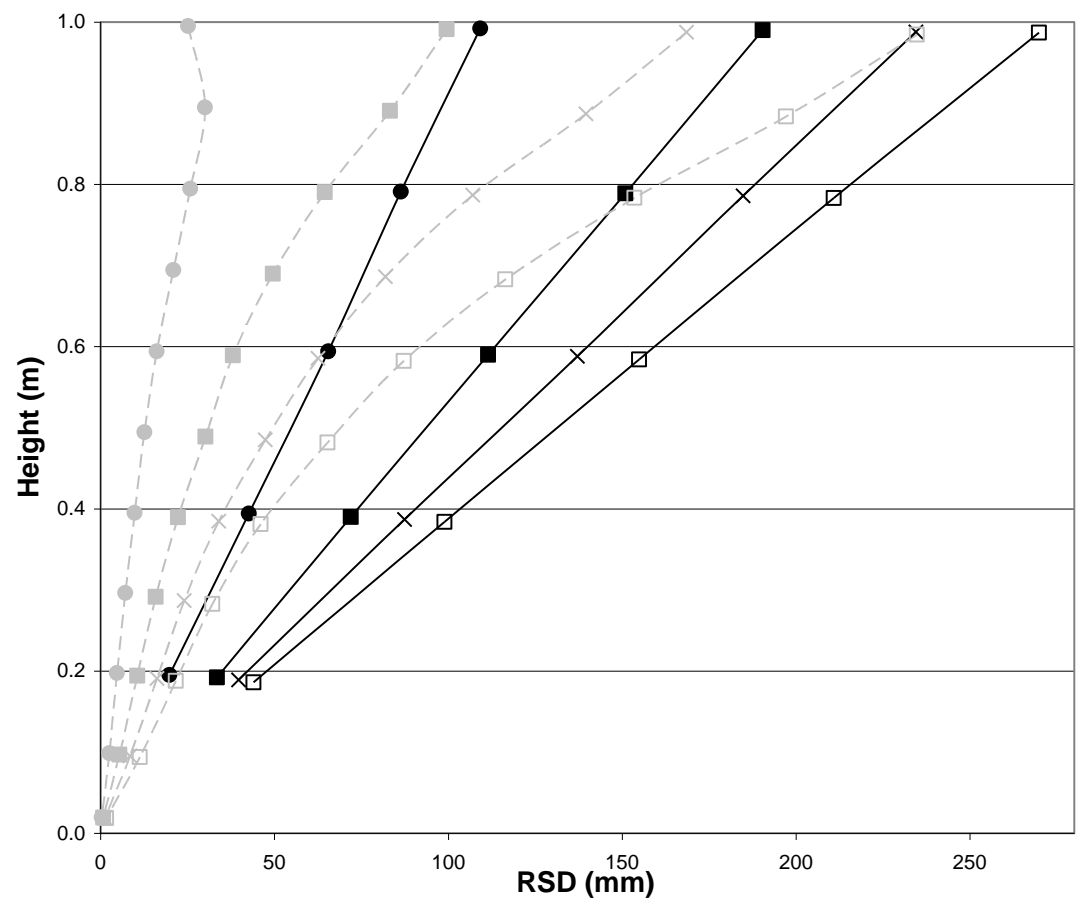

$\longrightarrow \mathrm{T} 313.5 \mathrm{kPa}$

$\rightarrow \mathrm{T} 335 \mathrm{kPa}$

$\leftarrow$ T3 $55 \mathrm{kPa}$

匹-T3 $75 \mathrm{kPa}$

- FLAC $13.5 \mathrm{kPa}$

- FLAC $35 \mathrm{kPa}$

$-\rtimes-$ FLAC $55 \mathrm{kPa}$

曰- FLAC $75 \mathrm{kPa}$

b)

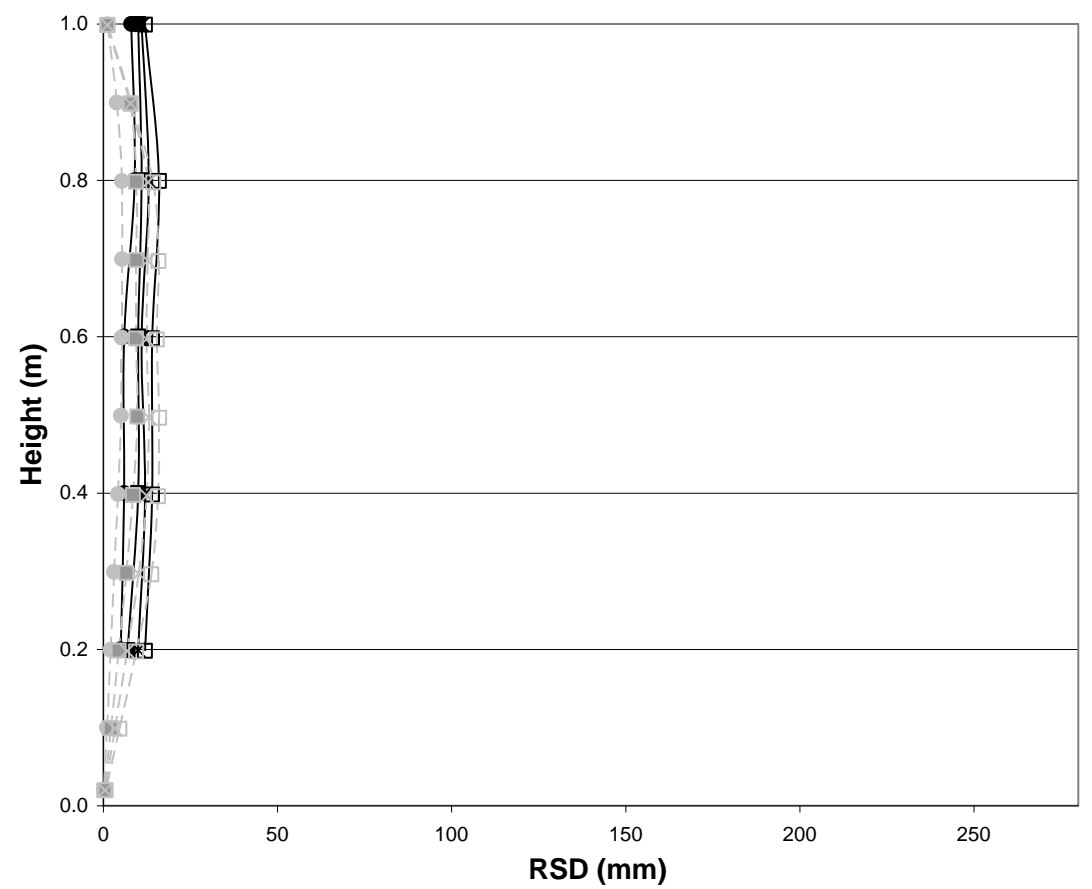

$\longrightarrow \mathrm{T} 313.5 \mathrm{kPa}$

$\longrightarrow \mathrm{T} 335 \mathrm{kPa}$

$\times$ T3 $55 \mathrm{kPa}$

— T3 $75 \mathrm{kPa}$

FLAC $13.5 \mathrm{kPa}$

픈- FLAC $35 \mathrm{kPa}$

$-x-$ FLAC $55 \mathrm{kPa}$

- - FLAC 75 kPa

c) 


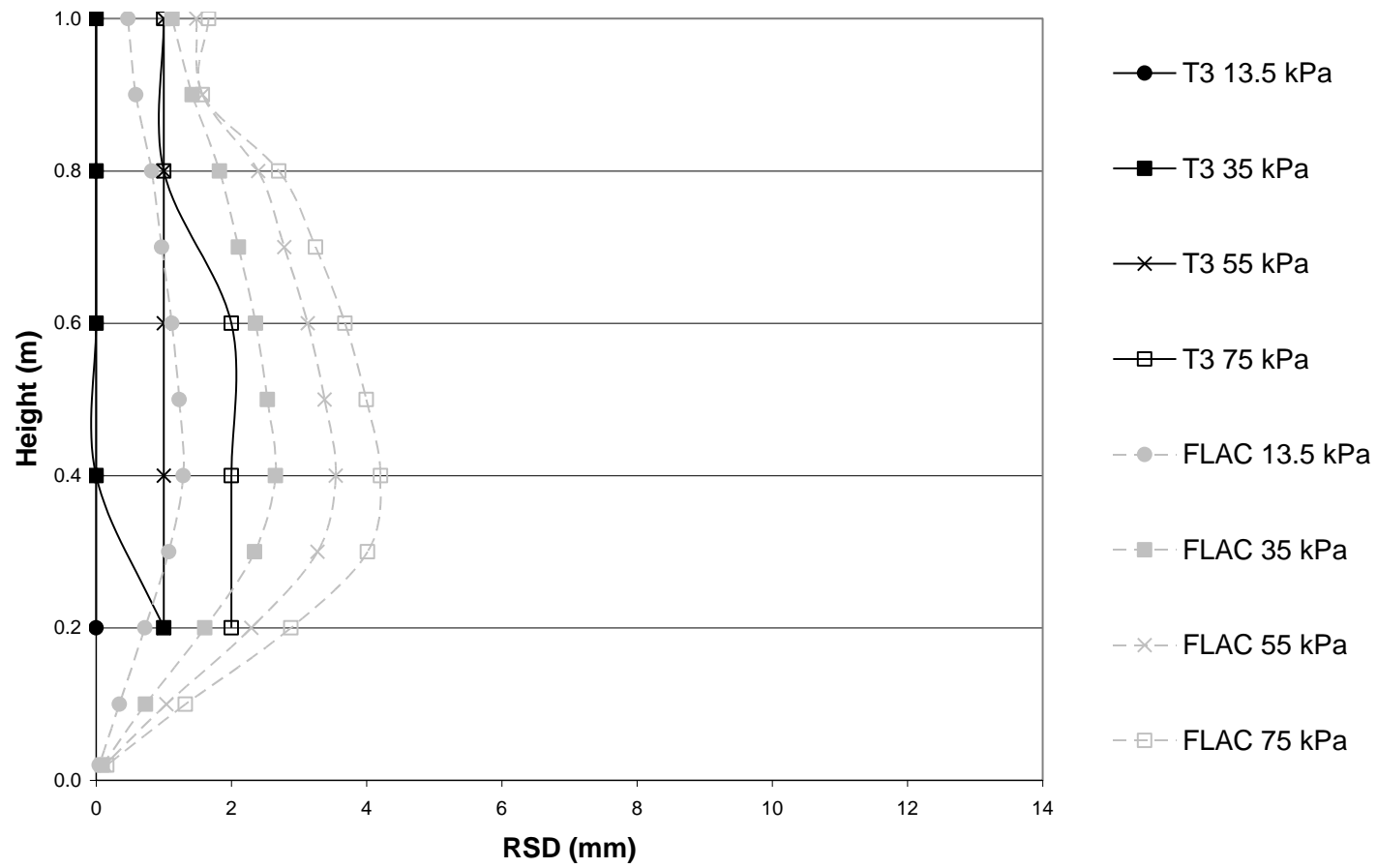

Figure 12 Relative interface shear displacements between a) synthetic waste vs. geotextile b) Type G textured HDPE geomembrane vs. geotextile and c) Type G smooth HDPE geomembrane vs. wooden subgrade. 
a)

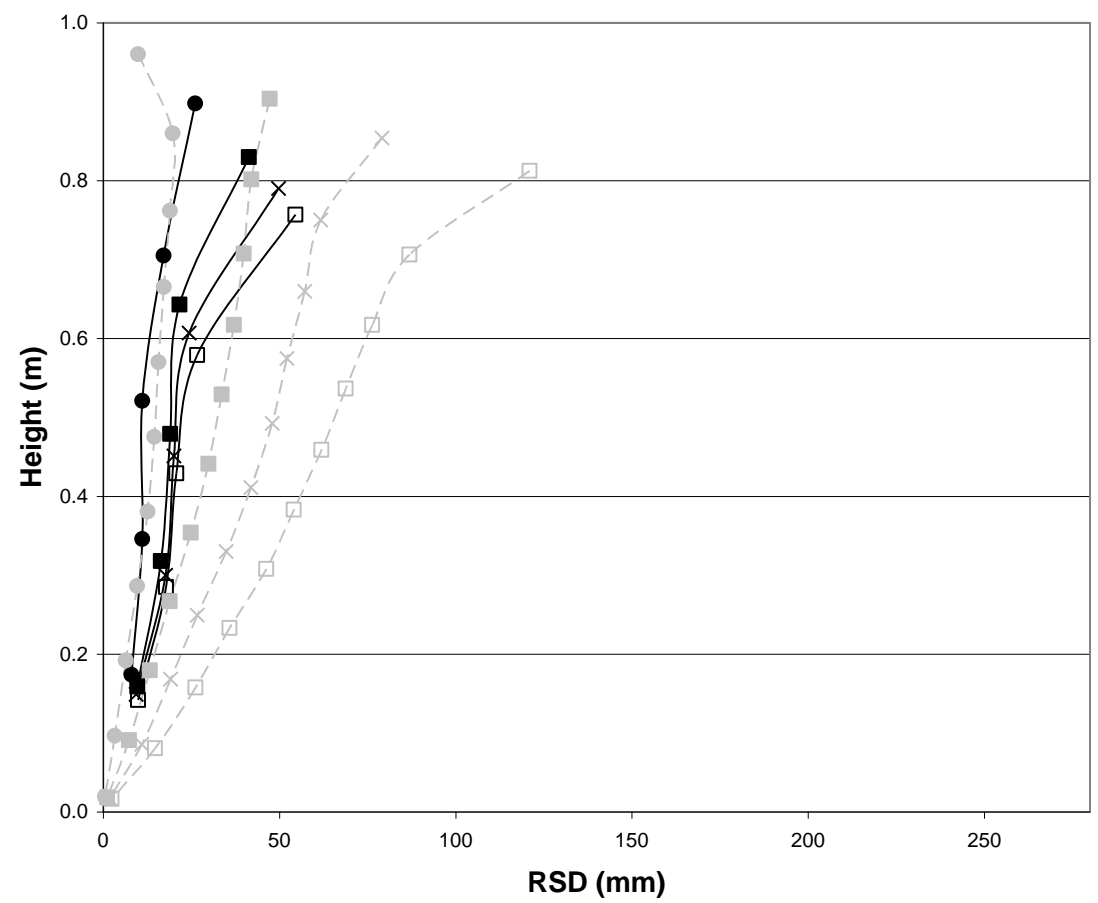

$$
\begin{aligned}
& \rightarrow \text { T4 } 13.5 \mathrm{kPa} \\
& \rightarrow-\mathrm{T} 435 \mathrm{kPa} \\
& - \text { T4 } 55 \mathrm{kPa} \\
& -\mathrm{T} 475 \mathrm{kPa} \\
& - \text { FLAC } 13.5 \mathrm{kPa} \\
& -\nsucc-\text { FLAC } 55 \mathrm{kPa} \\
& -\because-\text { FLAC } 75 \mathrm{kPa}
\end{aligned}
$$

b)

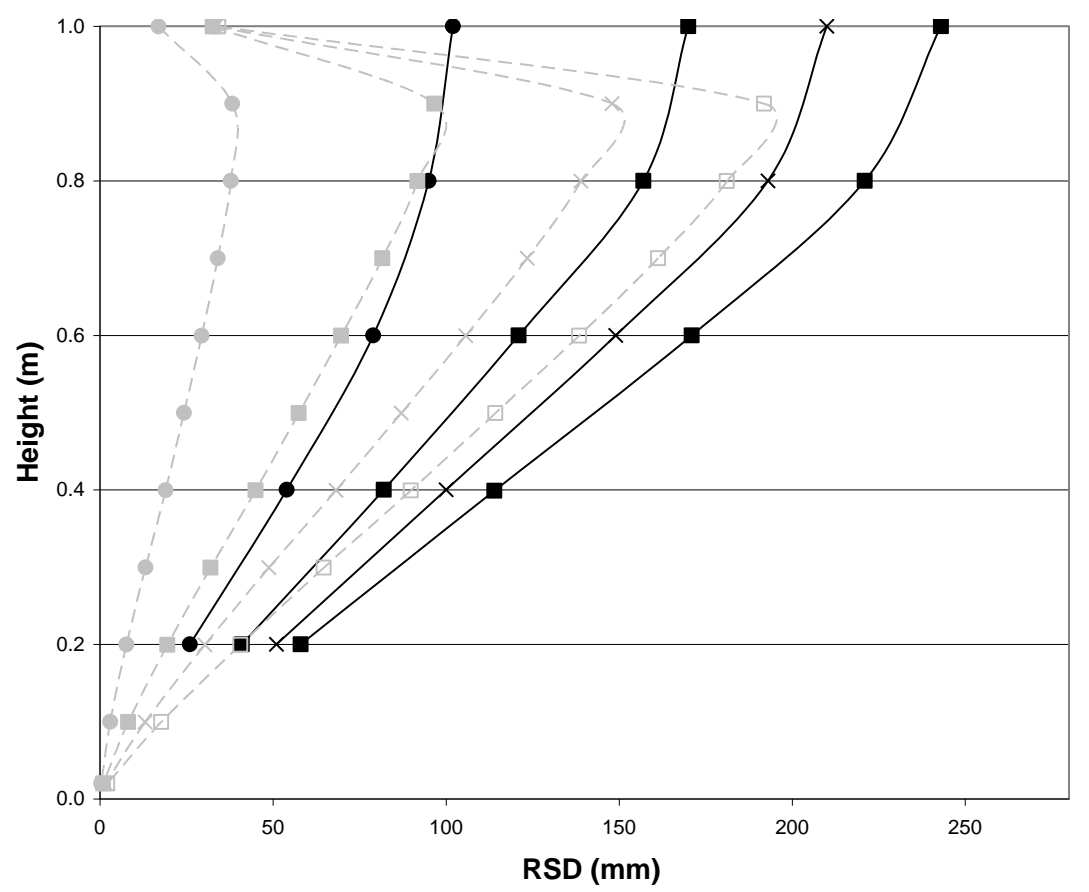

$$
\begin{aligned}
& \longrightarrow \text { T4 } 13.5 \mathrm{kPa} \\
& \rightarrow \mathrm{T} 435 \mathrm{kPa} \\
& \leftarrow \text { T4 } 55 \mathrm{kPa} \\
& \rightarrow \mathrm{T} 475 \mathrm{kPa} \\
& \text { - FLAC } 13.5 \mathrm{kPa} \\
& \text { FLAC } 35 \mathrm{kPa} \\
& -*-\text { FLAC } 55 \mathrm{kPa} \\
& \text { - }- \text { FLAC } 75 \mathrm{kPa}
\end{aligned}
$$

c) 


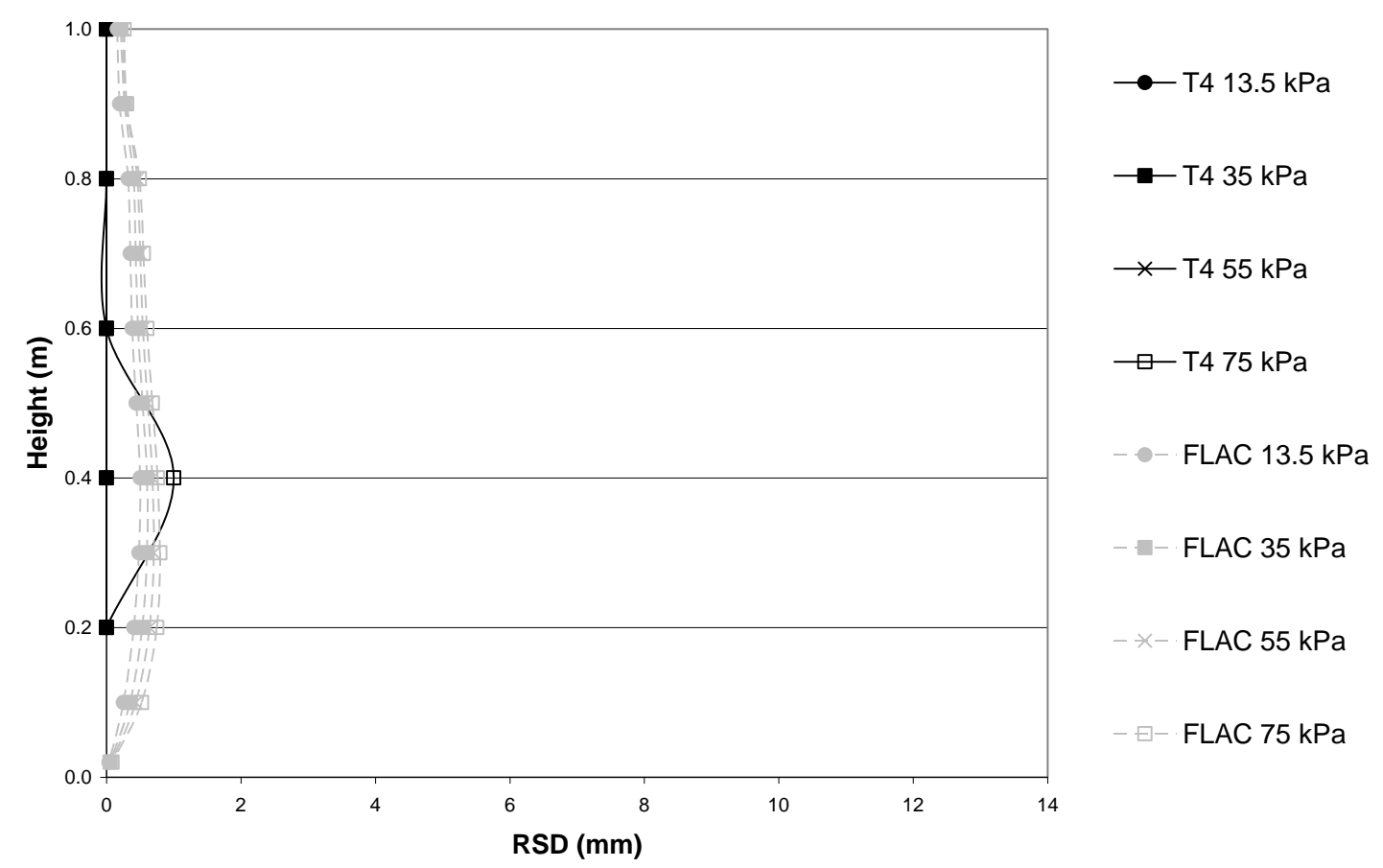

Figure 13 Relative interface shear displacements for a) synthetic waste vs. geotextile b) Type G smooth HDPE geomembrane vs. geotextile and c) Type G textured HDPE geomembrane vs. wooden subgrade.

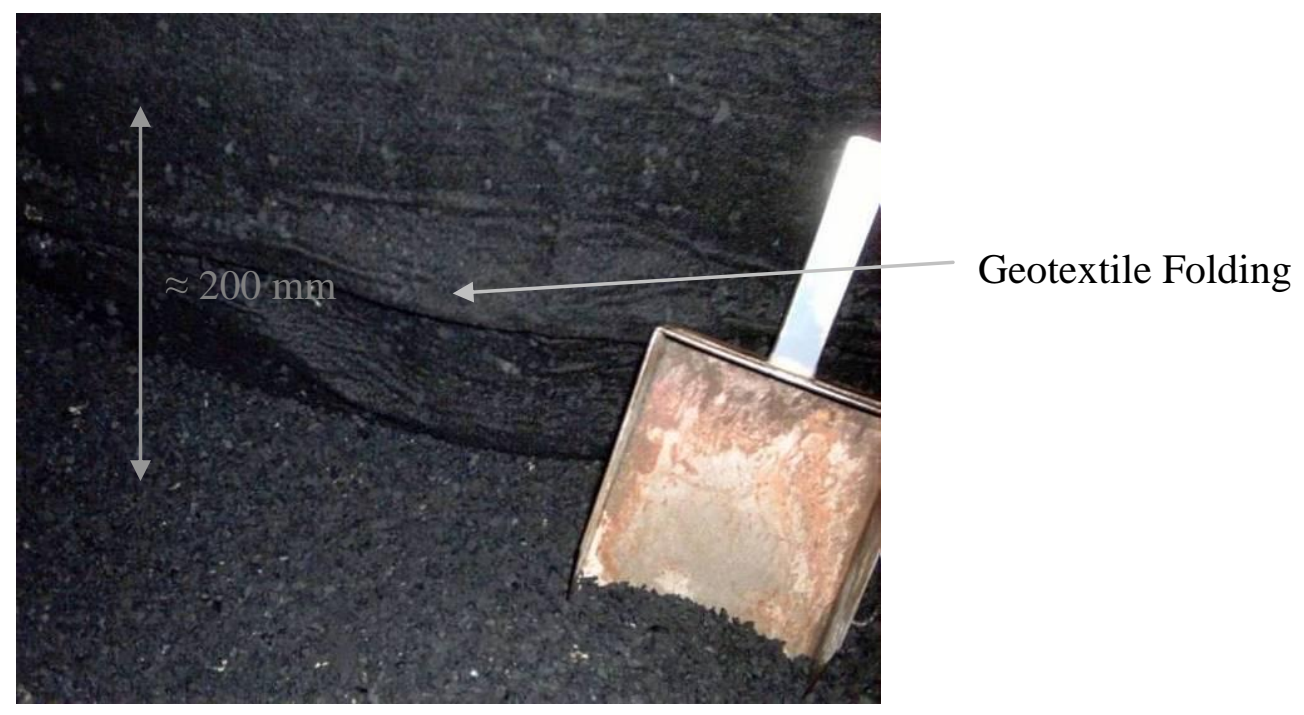

Figure 14 Geotextile folding in lower $200 \mathrm{~mm}$ (Test 4: HDPE Geomembrane: Smooth up) 
